\title{
Global Economic and Financial Crisis: India's Trade Potential and Prospects, and Implications for Asian Regional Integration
}

\author{
Prabir De \\ Research and Information System for Developing Countries
}

\begin{abstract}
This study estimates the trade potential for India using an augmented Gravity model and then attempts to determine the importance of trade remedies. Based on the panel data, this Gravity model is the first-ever attempt to estimate India's trade potential in the pre- and post- global economic and financial crisis period. The estimates of India's global trade potential reveal that the magnitude of India's trade potential is at its maximum in the Asia-Pacific region, followed by Africa and Latin America. Potential for expansion of trade in the post-crisis period is highest for countries such as China. However, in a large part of the world, India's trade has remained unrealized, which provides further opportunities to expand despite the slowdown in global demand. Nonetheless, there is a strong complementary role, as this study indicates; i.e., tariff liberalization and trade facilitation, which taken together can help build export momentum in the crisis period.
\end{abstract}

- JEL Classification: F1, F15, F17

- Key Words: Asia, India, trade, gravity model, financial crisis

\footnotetext{
*Corresponding address: Prabir De: Visiting Researcher, Asian Development Bank Institute (ADBI), Tokyo; and Fellow, Research and Information System for Developing Countries (RIS), Zone 4B, Fourth Floor, India Habitat Centre, Lodhi Road, New Delhi 110 003, India, Tel: (+91-11) 24682177 , Fax: (+91-11) 24682173 74, e-mail: prabirde@hotmail.com; prabirde@ris.org.in.

(C2010-Center for International Economics, Sejong Institution, Sejong University, All Rights Reserved.
} 


\section{Introduction}

The origin of India's current prosperity was not known until July 1991, when a crisis forced the Government to take the path of economic liberalization. Crisis means opportunities, as one Chinese proverb says; India has now emerged from the crisis that peaked in July 1991 when the country's foreign exchange reserves were reduced to finance for three weeks' worth of imports. It stemmed from large fiscal deficits in 1980s that culminated in an external payment crisis in $1991 .{ }^{1}$ In nontechnical terms, the balance of payment crisis in 1991 pushed the country to nearbankruptcy. India responded to the crisis by initiating far-reaching policy reforms under a New Economic Policy (NEP), primarily to reduce excessive government controls, liberalize trade, allow foreign investment, encourage private sector business, and gradually embrace globalization. The crisis of 1991 thus gave birth to a modern India. A fascinating story unfolded thereafter.

The NEP unleashed India's latent economic potential. India remarkably transformed itself from a slow-growing economy to one of the fastest growing economies in the world. The trade liberalization initiated in India in the aftermath of July 1991 has undoubtedly led to a perceptible change in the performance of the external sector. As a result, India's share in world exports of goods and services increased from about $1 \%$ in 1990 to about $4 \%$ in $2007 .{ }^{2}$ The rapid growth of India's trade, especially in the past decade and a half, represents both a structural change in gross domestic product (GDP) and a marked shift in export orientation. The share of trade in GDP increased from about $15 \%$ in 1990 to about $49 \%$ in $2007,{ }^{3}$ and average trade per capita increased to US\$ 389 in 2005-2007 from a meagre US\$ 94 in 1990-1992. ${ }^{4}$ Undoubtedly, India has benefited from the globalization process.

India is now facing another crisis, which, unlike 1991, has its origins abroad. The entire world is witnessing a financial turbulence following the sub-prime mortgage crisis in the United States of America. While the exact reasons are not yet known at the fundamental level, the crisis could be ascribed to the persistence of large global imbalances, which, in turn, is the outcome of long periods of

\footnotetext{
${ }^{1}$ The causes and consequences of the 1991 economic crisis have been dealt with extensively in the literature. See, for example, Jalan (1993).

${ }^{2}$ Taken in US dollar terms, and calculated based on World Trade Organization (2008, p. 81). This refers $1.04 \%$ for exports of goods and $2.73 \%$ in the case of exports of services in 2007 .

${ }^{3}$ In US dollar terms, calculated based on World Bank (2009).

${ }^{4}$ Taken from World Trade Organization (2008, p. 81).
} 
excessively loose monetary policy in the major advanced economies during the early part of this decade (Mohan, 2009). The unfolding global financial crisis is, however, having major repercussions in India that are different from that witnessed during 1991. Although the magnitude of the impact on India is still low, it could potentially weaken the economy through trade channels if not tackled properly, at a time when India is much more globalized than in the early 1990s (Acharya, 2009; Rakshit, 2009). Being in the midst of the global crisis, India too is facing deceleration in growth. ${ }^{5}$ The overall economic situation thus remains serious.

The current crisis threatens to undo the economic development achieved by many countries and to erode people's faith in an open international trading system (Lamy, 2009). According to the World Trade Organization (WTO) (2009a), "the collapse in global demand brought on by the biggest economic downturn in decades will drive exports down by roughly $9 \%$ in volume terms in 2009 , the biggest such contraction since the Second World War." With the increasing integration of the Indian economy and its financial markets with rest of the world, there is recognition that the country does face some downside risks from the global economic and financial crisis (Mohan, 2008; Subbarao, 2009). Nonetheless, if the crisis is prolonged, it will damage India's trade pattern and production structure, which have been built up over time (De and Neogi, 2009).

In turning the present crisis into opportunities, there is no doubt that India has to unfold another set of reforms as it did in the aftermath of the 1991 crisis in order to enhance its global trade and to strengthen the globalization process. It should be remembered that, India comes much behind other emerging economies such as China in international trade. With a population of more than 1 billion and a US\$ 1 trillion economy, India's trade potential is largely unrealized.

In view of the above, estimating India's global trade potential is therefore very topical in the context of the ongoing crisis. To estimate the global trade potential for India, this paper uses an augmented Gravity model equation with maximum possible geographical coverage of world trade flows. The policy implications will therefore highlight the need to anticipate relevant structural changes due to the

${ }^{5}$ For example, the Reserve Bank of India (RBI) in its latest 2009/10 Annual Policy Statement (APS), released on 21 April 2009, indicated that India's GDP growth in 2008/09 would be in the range of 6.5$6.7 \%$, decreased from 7\% projected in the January 2009 RBI policy review. The same RBI APS also indicates deceleration of growth will continue in $2009 / 10$ to around $6 \%$ with the assumption of a normal monsoon in 2009-10. Forecasts by IMF and other organizations on the growth of the Indian economy in the foreseeable future are no different. See Reserve Bank of India (2009). 
effect of the ongoing crisis in the medium to long term.

Section II of this paper discusses two important issues in India's trade, which motivates the other part of the paper. Section III represents the Gravity model methodology and data sources that are used to estimate India's trade potential. The main results are presented in Sections IV and V, while Section VI provides the conclusions and policy implications for Asian regional integration.

Table 1. India's Merchandise Trade

\begin{tabular}{|c|c|c|c|c|c|}
\hline \multirow{2}{*}{ Year } & Exports & Imports & Total & Trade in GDP & EPC* \\
\hline & \multicolumn{3}{|c|}{ (US\$ billion) } & $(\%)$ & (US\$) \\
\hline $1950 / 51$ & 1.27 & 1.27 & 2.54 & & 3.53 \\
\hline $1960 / 61$ & 1.35 & 2.35 & 3.70 & 11.77 & 3.10 \\
\hline $1970 / 71$ & 2.03 & 2.16 & 4.19 & 7.76 & 3.71 \\
\hline $1980 / 81$ & 8.49 & 15.87 & 24.36 & 15.56 & 12.34 \\
\hline 1990/91 & 18.15 & 24.07 & 42.22 & 15.48 & 21.36 \\
\hline $1995 / 96$ & 31.80 & 36.68 & 68.48 & 23.13 & 34.11 \\
\hline $2000 / 01$ & 44.56 & 50.54 & 95.10 & 27.38 & 43.86 \\
\hline $2001 / 02$ & 43.83 & 51.41 & 95.24 & 26.38 & 42.45 \\
\hline $2002 / 03$ & 52.72 & 61.41 & 114.13 & 29.92 & 50.28 \\
\hline $2003 / 04$ & 63.84 & 78.15 & 141.99 & 30.78 & 59.98 \\
\hline $2004 / 05$ & 83.54 & 111.52 & 195.06 & 38.22 & 77.37 \\
\hline $2005 / 06$ & 103.09 & 149.17 & 252.26 & 43.61 & 94.18 \\
\hline $2006 / 07$ & 126.26 & 185.60 & 311.86 & 48.78 & 113.77 \\
\hline $2007 / 08$ & 163.13 & 251.65 & 414.78 & 49.38 & 146.86 \\
\hline $2008 / 09$ & 168.70 & 287.76 & 456.46 & & 152.01 \\
\hline \multicolumn{6}{|c|}{ Average annual growth rate (\%) } \\
\hline $1950 \mathrm{~s}$ & 1.10 & 7.92 & & & \\
\hline $1960 \mathrm{~s}$ & 4.37 & -0.52 & & & \\
\hline $1970 \mathrm{~s}$ & 15.63 & 23.73 & & & \\
\hline $1980 \mathrm{~s}$ & 8.28 & 4.51 & & & \\
\hline $1990 \mathrm{~s}$ & 9.80 & 8.46 & & & \\
\hline $2000 / 01-2008 / 09$ & 18.62 & 24.90 & & & \\
\hline $1951 / 52-1990 / 91$ & 7.35 & 8.91 & & & \\
\hline 1991/92-2008/09 & 13.72 & 15.77 & & & \\
\hline $1951 / 52-2008 / 09$ & 9.32 & 11.04 & & & \\
\hline
\end{tabular}

Note: * EPC stands for export per capita

Sources: Calculated based on (a) "Economic Survey 2007-08", Ministry of Finance, Government of India, based on Director-General of Commercial Intelligence and Statistics (DGCIS), Ministry of Commerce and Industry, Government of India; and (b) press releases on India's foreign trade, (dated 1 April 2009 and 1 May 2009), New Delhi. 


\section{India's Trade and Two Critical Issues}

India's accelerated trade in the recent past has caught the world's attention. By any standard, Indian trade performance has greatly improved; export per capita has increased much more rapidly in the post-reform period than in earlier years (Table 1). Although, with an import substitution policy in place, India took two decades (1950/51 to 1969/70) to cross the US\$ 2 billion export mark, with a much more liberal policy the country crossed the US\$ 20 billion export milestone after just two years from 1991. Over time, with greatly reduced barriers to international transactions, Indian participation in the international economy has improved rapidly. Today, with a $19 \%$ per annum growth rate, India's exports have passed US\$ 169 billion (2008/09), while imports have increased to US\$ 288 billion, having grown at about 25\% per annum since 2000/01 (Table 1 and Figure 1). India's trade growth rate in the present decade has thus been the highest of all the decades since the 1950s. Higher growth in the post-1991 period helped India not only to enlarge but also to diversify its exports (Figure 2). ${ }^{6}$ India's success story in international trade is thus a well-documented case.

Figure 1. India's Trade since 1950/51

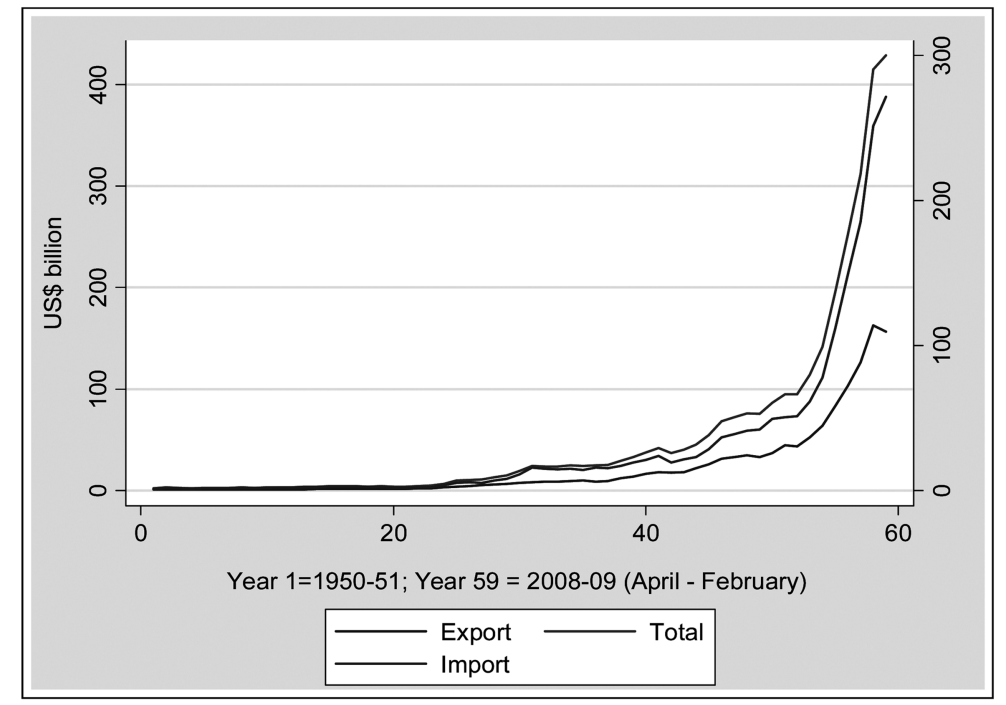

${ }^{6}$ The Trade Entropy Index (TEI) score (index of diversification) increased from 2.782 in 1995 to 2.710 in 2008 with a peak of 2.924 in 2006. TEI is a measure of geographical concentration or dispersion of exports. High values indicate greater uniformity in the geographical dispersion of exports (see, for example, Mikic and Gilbert, 2007). 
Figure 2. Trends in India's Trade Diversification

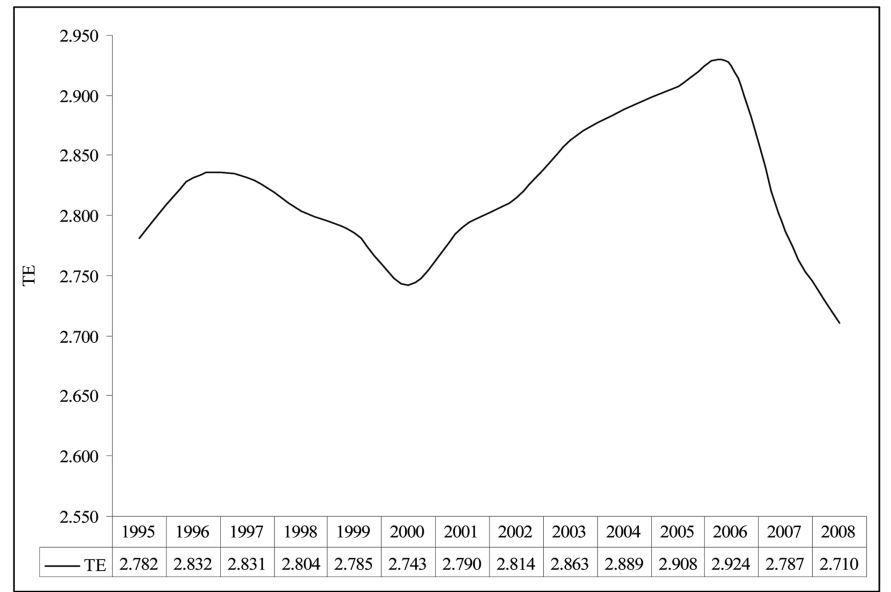

Note: TE stands for trade entropy

A strong set of literature shows trade liberalization initiatives in India have not always been complemented by trade-facilitating infrastructure, while those in China have been relatively well managed. ${ }^{7}$ Not surprisingly, India lies a long way behind China in so far as trade volumes are concerned.

One precondition of the trade-led globalization process is that trade liberalization has to be actively supported by a trade facilitating infrastructure, in terms of both hardware and software, in order to maximize trade welfare. Falling short of an adequate infrastructure will lead to sub-optimal trade; in other words, trade potential will remain unrealized. A properly estimated trade potential will help in enabling countries to take the necessary policy measures - i.e., either by retooling the export-led growth process, or by planning infrastructure (national and/or international) to support the country's rising trade and growth momentum.

In that regard, three important issues should be mentioned:

(a) Higher trade transaction costs are associated with India's exports (Figure 3);

(b) Even though peak tariffs have been reduced drastically, tariffs are still a major barrier to India's exports (Figure 4); and

(c) Taking together, trade transaction costs and tariffs are the two critical elements thus negatively affecting India's exports (Figure 5).

${ }^{7}$ See, for example, Brooks and Hummels (2009). 
Figure 3. India's Exports and Transaction Costs

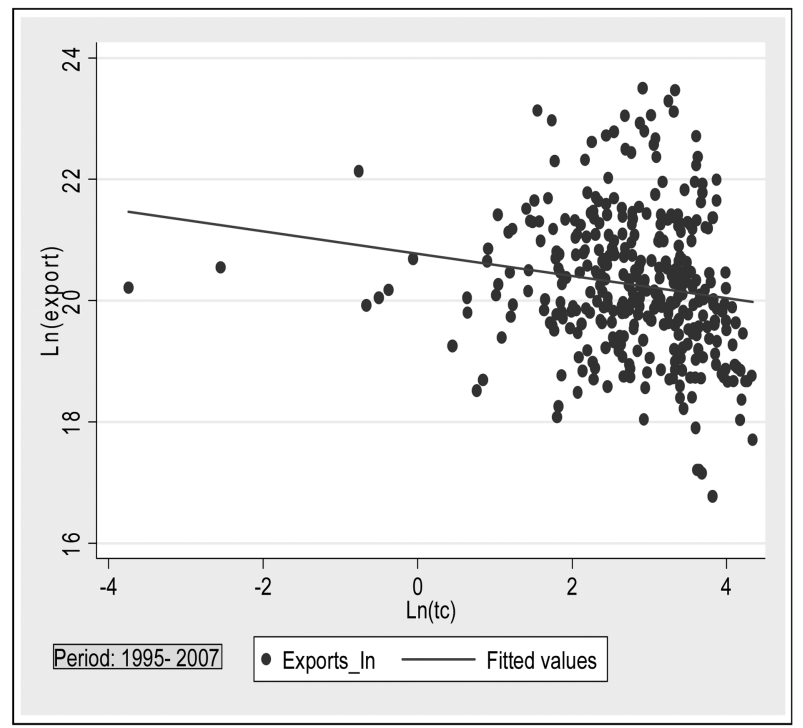

Figure 4. India's Exports and Partner's Tariff

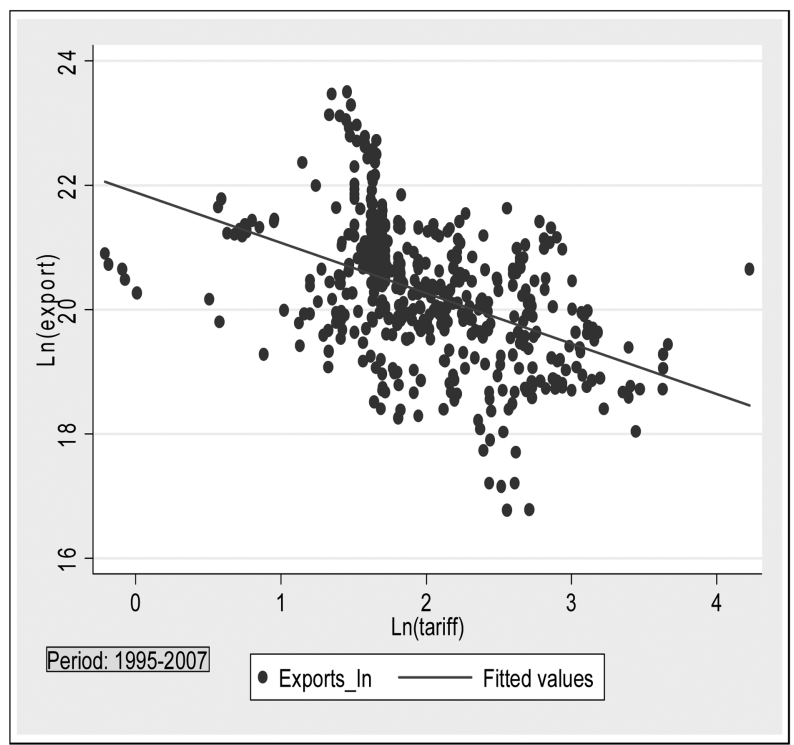

What follows is that the costs, delays, and uncertainties surrounding trade facilitation infrastructure services and importers' tariffs remain major obstacles to India's exports. How much trade can India generate if the conventional barriers are removed? What would be India's trade potential during the course of the ongoing crisis? Are the trade barriers already dead in the crisis or appearing with new 
Figure 5. Barriers to India's Exports: Trade Transaction Costs and Partner's Tariffs

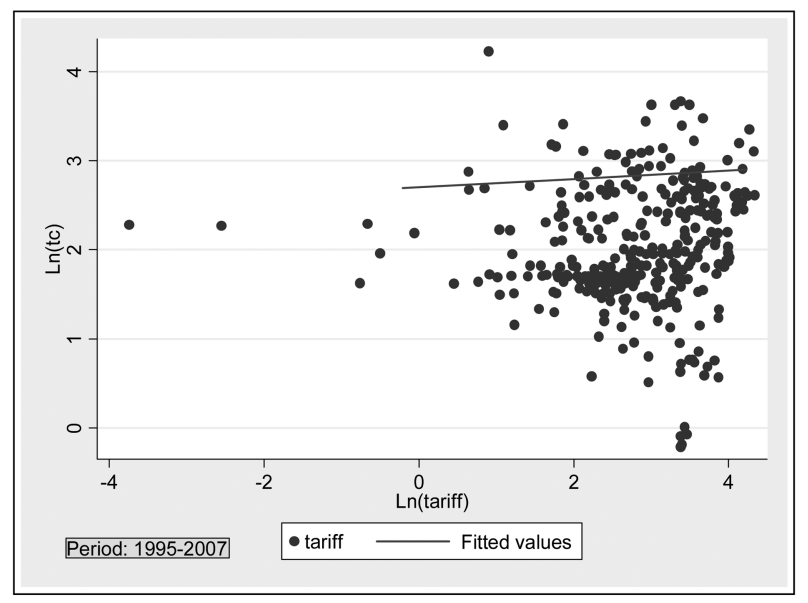

shapes? What are the magnitudes of barriers to India's trade? The next sections, in which an attempt is made to examine the trade and trade-frictions nexus in a Gravity model framework, are devoted to answering these questions.

\section{Measuring Trade Potential: the Gravity Model}

The Gravity model has been used extensively in empirical international trade since it was introduced by Tinbergen (1962), who empirically pointed out that trade between two countries was determined by their relative masses and their distance from each other. ${ }^{8}$ Over time, this model has been used largely in explaining the effects of different policies and other determinants of trade flows with the key variables of economic size and distance. Its popularity in empirics increased rapidly with the introduction of "theoretical" Gravity by Anderson and van Wincoop (2003 and 2004), which has become the de facto standard in empirical work. ${ }^{9}$ The Gravity model literature on empirical international trade now covers a wide spectrum of trade flows and trade barriers such as common currencies (Rose,

\footnotetext{
${ }^{8}$ Drawing an analogy from Newtonian physics, the Gravity model was first introduced in economics by Tinbergen (1962). Poyhonen (1963) and Linnemann (1966) were the next two studies that attempted to explain trade flows by augmenting the Gravity model. Since then, thousands of studies and analyses of international trade have been carried out based on an augmented Gravity model.

${ }^{9}$ Anderson (1979) was the first to attempt to provide a theoretical foundation for the Gravity model. Since the objective of this paper is to estimate trade potential using the Gravity model, a detailed discussion on the evolution of the model is thus beyond the scope of this analysis. However, for additional details about the model, see ARTNeT (2009) and Shepherd (2008).
} 
2000), trade costs (Harrigan, 2001; Baier and Bergstrand, 2001; Wilson et al., 2005; Djankov et al., 2006; Baier and Bergstrand, 2007; Jacks et al., 2008), international borders (McCallum, 1995; Anderson and van Wincoop, 2003; Gorodnichenko and Tesar, 2009), and methodological issues (Egger, 2000 and 2002; Baldwin and Taglioni 2006, 2007; Silva and Tenreyro, 2006; Helpman et al., 2008). To a great extent, "Gravity" has become the workhorse of empirical international trade.

As this study explains, numerous applications of the Gravity model were found for looking at different types of trade costs and their impacts on trade flows. A minute scrutiny indicates most of them have focused on "policy" barriers such as tariffs and non-tariff barriers, regional integration agreements, currency unions, and the General Agreement on Tariffs and Trade (GATT)/WTO, time delays in export/ import and trade facilitation, governance, and anti-corruption and contract enforcement. On the other hand, very few applications have dealt with "nonpolicy" barriers such as transport costs, infrastructure barriers, etc. explicitly in the Gravity model, the exceptions being Duval and Utoktham (2009), Francois et al. (2009), Moreira et al. (2008), De (2008a and 2008b), Hoekman and Nicita (2008), Francois and Manchin (2006), Nordås and Piermartini (2004), and Bougheas et al. (1999).

While the Gravity model has been increasingly used in international trade to estimate trade potential, ${ }^{10}$ only Batra (2004) was found to have used the Gravity model to estimate India's trade potential. However, the Gravity model was also used in some recent studies to estimate South Asia's trade potential. ${ }^{11}$

In the first part of this paper, the approach is to estimate the trade potential between India and its partner countries for (a) the pre-crisis and (b) the post-crisis periods. This is done based on an augmented Gravity model in its most basic form, and explains that bilateral trade is proportional to the product of economic sizes of country pairs and inversely related to the distance between them. The basic Gravity model has therefore taken the following shape:

$$
\ln \left(T_{i j}\right)=\alpha+\beta_{1} \ln \left(Y_{i} \cdot Y_{j}\right)+\beta_{2} \ln \left(D_{i j}\right)
$$

Augmenting the basic Gravity model equation (1), controlling for dummy

\footnotetext{
${ }^{10}$ See, for example, Kalirajan and Bhattacharya (2007), Armstrong et al. (2008), Shepotylo (2009), and Helble et al. (2007).

${ }^{11}$ See, for example, RIS (2008), ADB-UNCTAD (2008), and Moktan (2008).
} 
variables that influence the trade flows, we get

$$
\ln \left(T_{i j}\right)=\left(\alpha+\beta_{1} \ln \left(Y_{i} . Y_{j}\right)+\beta_{2} \ln \left(D_{i j}\right)+\beta_{3}\left(\operatorname{Adj}_{i j}\right)+\beta_{4}\left(\operatorname{Lang}_{i j}\right)+\beta_{5}\left(R T A_{i j}\right)+\varepsilon_{i j}\right)
$$

where $T_{i j}$ is bilateral total trade flow (export plus import, taken in US dollars at current prices) between countries $i$ and $j, Y_{i}$ and $Y_{j}$ represent the economic size of countries $i$ and $j$ (here represented by countries' GDP taken at current US dollar value), $D_{i j}$ is the bilateral distance between countries $i$ and $j, \operatorname{ADJ}_{i j}$ is a dummy variable to identify a pair of countries that are geographically adjacent or contiguous, or which share a border ( $=1$ if they are adjacent, 0 otherwise), $\operatorname{Lang}_{i j}$ is a dummy variable to capture language similarity between a pair of countries $(=1$ if they have language similarity, 0 otherwise), $\mathrm{RTA}_{i j}$ is a dummy variable that represents if a pair of countries have any regional trading arrangement in the form of a preferential trade agreement (PTA) or free trade agreement (FTA), and $\varepsilon_{i j}$ is a log-normally distributed error term.

The second part of this paper attempts to assess the impact of tariff and trade transaction costs on India's exports by augmenting equation (1), following Helble et al. (2007). Here, a world of $N$ countries and a continuum of differentiated goods are considered. It is assumed that countries specialize in a range of goods and that consumers have constant elasticity of substitution (CES) preferences. ${ }^{12}$ Following Anderson and van Wincoop (2003 and 2004), a theoretically consistent Gravity model is then applied for using panel data of exports from economy $i$ to economy $j$ in sector $k\left(X_{i j}^{k}\right)$. It takes the following shape:

$$
X_{i j}=\frac{Y_{i} Y_{j}}{Y^{w}}\left(\frac{t_{i j}}{\prod_{i} P_{j}}\right)^{1-\sigma}
$$

where $Y_{i}$ and $Y_{j}$ are the income levels of countries $i$ and $j, Y^{w}$ is total world income and $\sigma>1$ is the elasticity of substitution. The trade cost factor, $t_{i j} \geq 1$, is defined as the gross bilateral cost of importing a good (one plus the tariff equivalent), so that if $p_{i}$ is the supply price of a good produced in country $i$, then $p_{i j}=t_{i j} p_{i}$ is the price faced by consumers in country $j . \Pi_{i}$ and $\mathrm{P}_{j}$ are country $i$ 's outward and country $j$ 's inward multilateral resistance variables, respectively. These capture the countries' average international trade barriers. The important insight of the model is that

\footnotetext{
${ }^{12}$ It is assumed that all goods are differentiated by place of origin and that each country is specialized in the production of only one good. Therefore, the supply of each good is fixed $\left(n_{i}=1\right)$, but it allows preferences to vary across countries subject to the constraint of market clearing (CES).
} 
bilateral trade flows $X_{i j}$ depend on the bilateral trade barrier $t_{i j}$ relative to average international trade barriers. Taking the $\log$ of equation (3) and applying it to sector $k$, we get

$$
\begin{aligned}
\ln \left(X_{i j}^{k}\right)= & \ln \left(Y_{i}^{k}\right)+\ln \left(Y_{j}^{k}\right)-\ln \left(Y_{w}^{k}\right)+\left(1-\sigma_{k}\right) \ln \left(t_{i j}^{k}\right) \\
& -\left(1-\sigma_{k}\right) \ln \left(P_{j}^{k}\right)-\left(1-\sigma_{k}\right) \ln \left(\Pi_{i}^{k}\right)+\varepsilon_{i j}^{k}
\end{aligned}
$$

where $\mathrm{Y}_{\mathrm{i}}^{\mathrm{k}}$ is output of economy $i$ in sector $k, \mathrm{Y}_{\mathrm{j}}^{\mathrm{k}}$ is output of economy $j$ in sector $k$, $\mathrm{Y}^{\mathrm{k}}{ }_{\mathrm{w}}$ is aggregate (world) output in sector $k, \sigma_{\mathrm{k}}$ is elasticity of substitution in sector $k, \mathrm{t}_{\mathrm{ij}}{ }^{\mathrm{k}}$ represents trade costs facing exports from economy $i$ to economy $j$ in sector $k$, $\omega_{i}^{k}$ is economy $i$ 's output share in sector $k, \omega_{j}^{k}$ is economy $j$ 's expenditure share in sector $k$, and $\omega_{i j}^{k}$ is a random error term, satisfying the usual assumptions. Inward resistance $\left(P_{j}^{k}\right)^{1-\sigma_{k}}=\sum_{i=1}^{N} \Pi_{i}^{\sigma_{k}-1} \omega_{i}^{k}\left(t_{i j}^{k}\right)^{1-\sigma_{k}}$ captures the fact that country $j$ 's imports from country $i$ depend on trade costs across all suppliers. Outward resistance, by contrast, captures the dependence of exports from $i$ to $j$ on trade costs across all importers.

Before implementing this model in an empirical setting, bilateral trade costs $\left(t^{k}{ }_{i j}\right)$ need to be specified in terms of observable variables. It is assumed from equation (4) that $t^{k}{ }_{i j}$ captures several trade costs components, namely, infrastructure quality, tariff barriers, transport costs and other border effects. Assuming a monopolistically competitive market, the term $(1-\sigma)$ should be negatively related to volume of trade. Therefore, the importer's applied tariffs $\left(1+\tau^{k} i j\right)$ are included as well as the ad valorem equivalent of trade transaction costs $\left(1+t c^{k}{ }_{i j}\right)$. Then $t c^{k}{ }_{i j}$ is

estimated using $t c_{i j}^{k}=\frac{\operatorname{import}_{j}^{k}-\text { export }_{i}^{k}}{\operatorname{export}_{i}^{k}}$, where the import price is taken at $c i f$ and the export price is taken in $f o b$ for sector $k$ in bilateral pair. The overall direct trade transaction costs for export from country $i$ and to country $j$ are then embedded in $t c^{k}{ }_{i j}$. Additional factors are captured using a set of bilateral (economy - pair) fixed effects $\left(\alpha_{i j}\right)$.

$$
\ln \left(t_{i j}^{k}\right)=\beta_{1} \ln \left(1+\tau_{j}^{k}\right)+\beta_{2} \ln \left(1+t c_{i j}^{k}\right)+\sum_{i \neq j} \alpha_{i j}
$$

Substituting equation (5) into (4) and including sector fixed effects in addition to economy-pair fixed effects gives the baseline estimating equation: 


$$
\begin{aligned}
\ln \left(X_{i j}^{k}\right)= & \sum_{i \neq j} \alpha_{i j}+\beta_{1} \ln \left(Y_{i}\right)+\beta_{2} \ln \left(Y_{j}\right)+\beta_{3} \ln \left(1+\tau_{j}^{k}\right) \\
& +\beta_{4} \ln \left(1+t c_{i j}^{k}\right)+\beta_{5} \ln \left(D_{i j}\right)+\sum \gamma_{k}+\varepsilon_{i j}^{k}
\end{aligned}
$$

Therefore, trade is a product of the scale and structure of partner economies, their geographic, political and institutional proximity, and openness of their economies to trade, and trade barriers. In the particular case here, the final estimable equation (modifying the equation (6) suitably) takes the following shape:

$$
\begin{aligned}
\ln \left(X_{i j}\right)= & \sum_{i \neq j} \alpha_{i j}+\beta_{1} \ln \left(Y_{i}\right)+\beta_{2} \ln \left(Y_{j}\right)+\beta_{3} \ln \left(1+\tau_{j}\right)+\beta_{4} \ln \left(1+t c_{i j}\right) \\
& +\beta_{5} \ln \left(D_{i j}\right)+\beta_{6}\left(A d j_{i j}\right)+\beta_{7}\left(\operatorname{Lang}_{i j}\right)+\beta_{8}\left(R T A_{i j}\right)+\varepsilon_{i j}
\end{aligned}
$$

Equation (2) is used to analyse the trade flows, and the coefficients thus obtained are then used to estimate India's trade potential under various scenarios, while equation (7) is used to assess the impact of trade barriers on India's exports. Both the augmented Gravity models consider a panel data for the 13-year period from 1995 to 2007.

The data for the Gravity model are collected from several secondary sources and taken in bilateral pairs. Appendix A provides the list of data sources and classifications. The model considers data at the bilateral level for all the variables for their individual partners. By including tariffs and transaction costs, it covers a major portion of trade costs. All nominal values in equation (7) have been converted into constant terms in bilateral pairs, using a country-specific GDP deflator. The usual caveat is that India's major trade partners are considered for 1995 to 2007 in equation (7), which covers about 90\% of India's exports in each year. The trade potential is related to the calendar year and may not match with the actual trade realized in the financial year.

Equation (2) has been estimated using the panel data regression with the dependent variable of total merchandise trade between pairs of countries, whereas export replaces total trade as dependent variable in equation (7). Equation (2) has been estimated based on India's 172 bilateral trade partners, of which the major 38 partners are used while estimating equation (7).

A cross-section model does not explain the variance in bilateral trade flows when there is a time-specific impact on trade flows. Since there are significant and 
systematic variations of export patterns across trade partners, a satisfactory model of bilateral exports should explain substantial heterogeneity of exports at the country level. Therefore, panel data are used since they can better explain the relevant relationships between trade flows and trade barriers over time when there are both time-variant and time-invariant exogenous variables. Use of panel data has the advantage of better capturing the dynamic relationship between endogenous and exogenous variables - more variability, less collinearity, greater degrees of freedom and more efficiency. Individual country and time effects are used interchangeably in the models.

The following regression diagnostics were carried out for both the models (equations 2 and 7 ): ${ }^{13}$

- Linearity assumption between response variable and predictors was checked;

- Statutory hypothesis tests were carried out on the parameter estimates;

- Ramsey tests were done to check model specification;

- Normality of residuals was tracked through Kernel density plot;

- All estimates were checked for heteroscedasticity through the Breusch-Pagan/ Cook-Weisberg test for heteroscedasticity. Cameron and Trivedi's decomposition of IM-test was also used as an alternative;

- Multi-collinearity problems were checked by looking at partial correlations (see Appendix B) and then by using variance inflation factor (VIF) $;^{14}$

- Models do not suffer from endogeneity as highly correlated exogenous variables are not used in the Gravity equations. However, the possibility of endogeneity can not be ruled out in equation (7). To resolve this problem, instrumental variables (IV) estimations have been used in two-stage least squares (2SLS) framework. The populations of exporting and importing countries have been used as the instrumental variable in all the models. Nonetheless, use of the instrumental variable technique does not alter the coefficients of any of the variables to any significant extent, thereby implying

\footnotetext{
${ }^{13}$ These text book-type diagnostics have been done through Stata 10 . We ignore placing the results due to space constraints. However, the same can be made available to interested readers on request.

${ }^{14}$ As a rule of thumb, a variable whose VIF values are greater than 10 may merit further investigation. Tolerance, defined as $1 / \mathrm{VIF}$, is used by many researchers to check on the degree of collinearity. A tolerance value lower than 0.1 is comparable to a VIF of 10 . It means that the variable could be considered as a linear combination of other independent variables (refer to Stata 10)

${ }^{15}$ The Hausman test examines the null hypothesis that the coefficients estimated by the efficient random effects estimator are the same as the ones estimated by the consistent fixed effects estimator. If they are the same (insignificant P-value, Prob $>$ chi2 larger than 0.05), it is safe to use random effects (Hausman, 1978).
} 
that the endogeneity of income does not lead to any significant distortion of the initially postulated relationship in the Gravity model;

- Selection of model, fixed or random, was based on the Hausman $\chi^{2}$ test. ${ }^{15}$ For the fixed effect specifications, the OLS method has been used, while the random effects models have been estimated using the GLS method, correcting for possible heteroscedastic errors and panel specific serial correlation;

- The presence of serial correlation, if any, was detected through the DurbinWatson (DW) test;

- Alternative estimations such as the maximum likelihood estimation (MLE) and frontier maximum likelihood estimation (FMLE) were also made in order to check the relative robustness of the models.

\section{India's Trade Potential: Estimation Results}

Against the background of the ongoing economic and financial crisis, and the assumption that international trading arrangements are far from optimal, it is timely

Table 2. Non-linear Gravity Model Estimates

\begin{tabular}{lcc}
\hline \multicolumn{3}{c}{ Dependent variable: Log of total trade Panel: 1995 to 2007} \\
\hline & OLS $^{\mathrm{a}}$ & $\mathrm{GLS}^{\mathrm{b}}$ \\
Economic size $\left(\mathrm{GDP}_{i}^{*} \mathrm{GDP}_{j}\right)$ & $0.740^{* *}$ & $0.694^{* *}$ \\
& $(41.52)$ & $(16.73)$ \\
Distance $\left(\mathrm{D}_{i j}\right)$ & $-0.721^{* *}$ & $-0.789^{* *}$ \\
& $(-13.01)$ & $(-5.487)$ \\
Adjacency $\left(\mathrm{ADJ}_{i j}\right)$ & $0.964^{* *}$ & $0.975^{* *}$ \\
& $(3.333)$ & $(2.618)$ \\
Language $\left(\operatorname{Lang}_{i j}\right)$ & $0.491^{* *}$ & $0.526^{*}$ \\
& $(6.561)$ & $(2.537)$ \\
RTA $\left(\mathrm{RTA}_{i j}\right)$ & $0.698^{* *}$ & $0.319^{*}$ \\
& $(5.684)$ & $(2.456)$ \\
\hline Observations & 2205 & 2205 \\
R-squared & 0.686 & 0.689 \\
Wald $\chi^{2}$ & & 1422.69 \\
Prob $>\chi^{2}$ & & 0.000 \\
\hline
\end{tabular}

Notes: ${ }^{a}$ Fixed effect. ${ }^{b}$ Random effect. (Selection of random effect over fixed effect was based on the Hausman test.)

Robust $t$-statistics in parentheses for OLS and z-statistics for GLS ${ }^{* *} p<0.05,{ }^{*} p<0.1$. Countrypair effects are included in the model. All variables except dummies taken in log. All results are checked for robust standard errors and heteroscedasticity. GDP and trade were taken in the models at current US dollar value. 
to estimate India's trade potential amidst the crisis. Table 2 presents the estimated results of equation (2). Both the models explain about $69 \%$ of the variation in bilateral trade flows. All the basic features of the gravity model performed well; estimated coefficients are statistically significant, robust, and show correct signs and magnitudes. The Gravity results show that the higher the economic sizes in each pair of trade partners, the higher the trade. Given that the GDP coefficient is less than one (0.694), an increase in the economic size of the country (output) increases trade, although less than proportionately. ${ }^{16}$ The estimated coefficient of the distance variable has the expected sign and less than one (-0.789). Adjacency, Language and RTA dummies do carry expected signs and are statistically significant.

Table 3 lists countries that show the possibility of trade expansion at the bilateral level. The magnitude of India's trade potential is very high with countries in South Asia such as Pakistan (US\$ 18.76 billion), Bangladesh (US\$ 6 billion), and countries in Central Asia such as Kazakhstan (US\$ 1.2 billion), countries in the Middle East such as Kuwait (US\$ 1.9 billion), among others. Looking at the regional distribution, India's trade expansion hinges upon new countries (new markets) located across the world, of which the concentration of African and Latin American countries is more significant. The gap in potential trade is lowest in the case of Canada $(0.43 \%)$. At the same time, the magnitude of India's trade expansion is maximum with Pakistan, with which India trades about US\$1.22 billion, but which offers a potential of expansion of US\$18.76 billion (P/A = 15.32). With more than $60 \%$ gap in trade potential $(\mathrm{P} / \mathrm{A}=2.53)$, Bangladesh comes next. Contrary to popular belief, India's trade with adjacent countries such as Pakistan and Bangladesh is largely unrealized. ${ }^{17}$

India's trade with China (including Hong Kong, China) is expanding and is currently valued at US\$ 50 billion with a potential for further expansion of US\$ 58 billion. India also has potential for expansion of trade with developed countries in the European Union (e.g., Germany), North America (e.g., the United States) and

\footnotetext{
${ }^{16}$ See Appendix C for Maximum Likelihood Estimation (MLE) and Frontier MLE, carried out as alternative estimations. However, due to unsatisfactory results, compared to GLS, they could not be used.

${ }^{17}$ Similar observations were also reported by the Research and Information System for Developing Countries (RIS, 2008), according to which the, potential of intra-South Asia trade is about US\$ 40 billion compared with the existing formal trade of US\$ 10.5 billion. The report concluded that such a high extent of underutilization of the intraregional trade potential could be explained in terms of a substantial proportion of informal trade, lack of supply capabilities and the presence of high trade barriers.
} 
Table 3. Countries with Potential for Expansion of Trade

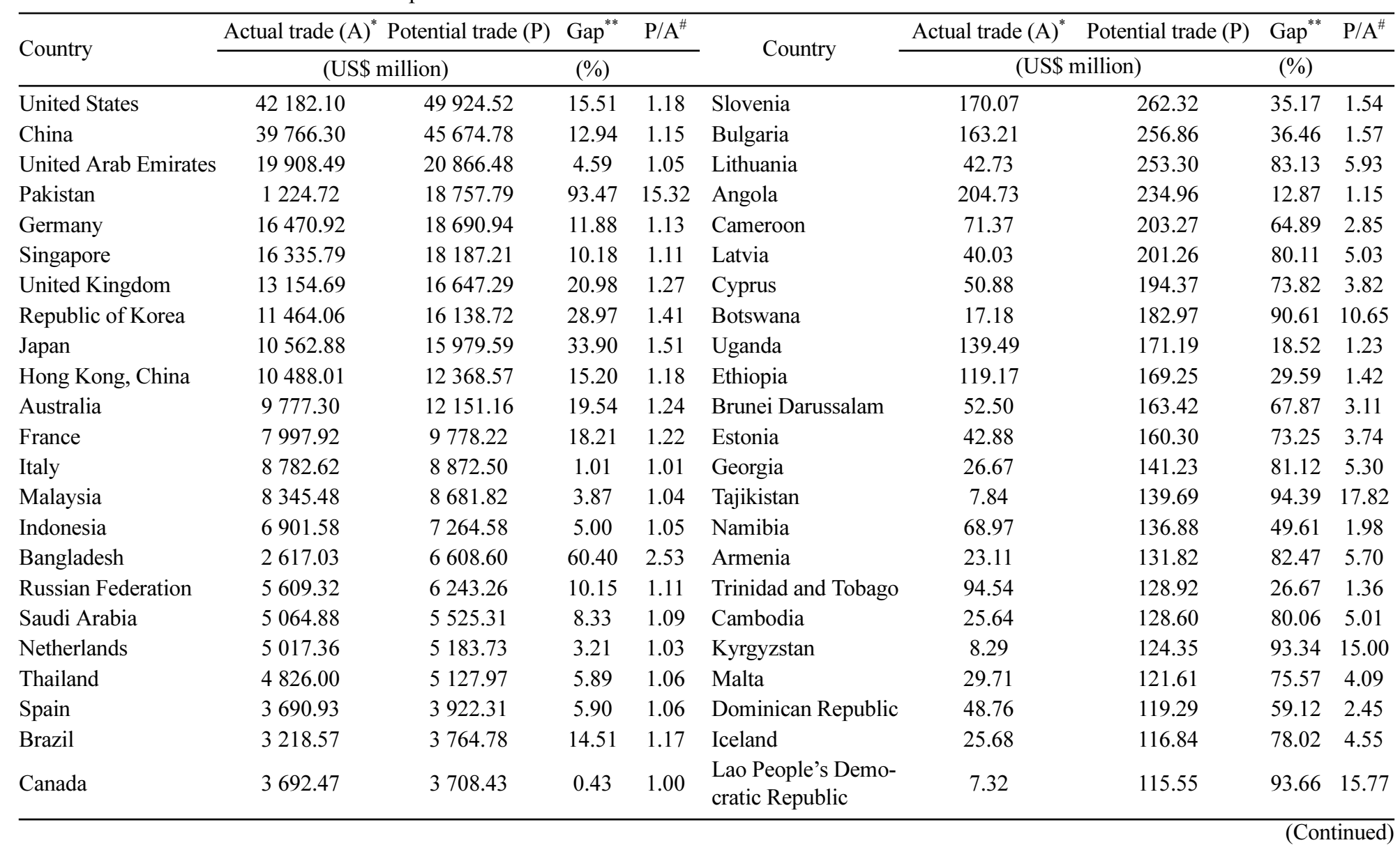


Table 3. Countries with Potential for Expansion of Trade(Continued)

\begin{tabular}{|c|c|c|c|c|c|c|c|c|c|}
\hline \multirow[t]{2}{*}{ Country } & $\begin{array}{l}\text { Actual trade } \\
\text { (A) }\end{array}$ & $\begin{array}{l}\text { Potential } \\
\text { trade }(\mathrm{P})\end{array}$ & Gap $^{* *}$ & $\mathrm{P} / \mathrm{A}^{\#}$ & \multirow[t]{2}{*}{ Country } & \multirow{2}{*}{\multicolumn{2}{|c|}{$\begin{array}{l}\text { Actual trade Potential trade } \\
\begin{array}{cc}(\mathrm{A})^{*} & (\mathrm{P}) \\
& (\mathrm{US} \$ \text { million })\end{array}\end{array}$}} & \multirow{2}{*}{$\begin{array}{c}\text { Gap }^{* *} \\
(\%)\end{array}$} & \multirow[t]{2}{*}{$\mathrm{P} / \mathrm{A}^{\#}$} \\
\hline & \multicolumn{2}{|c|}{ (US\$ million) } & \multicolumn{2}{|l|}{$(\%)$} & & & & & \\
\hline South Africa & 3262.12 & 3441.21 & 5.20 & 1.05 & Uruguay & 47.15 & 103.42 & 54.41 & 2.19 \\
\hline Israel & 3310.07 & 3377.67 & 2.00 & 1.02 & Albania & 23.35 & 100.10 & 76.67 & 4.29 \\
\hline Sri Lanka & 2939.67 & 3244.89 & 9.41 & 1.10 & Guatemala & 68.15 & 97.39 & 30.03 & 1.43 \\
\hline Chile & 2621.62 & 2963.25 & 11.53 & 1.13 & Jamaica & 27.20 & 85.63 & 68.23 & 3.15 \\
\hline Nepal & 2439.93 & 2669.66 & 8.61 & 1.09 & Mongolia & 2.53 & 71.58 & 96.47 & 28.29 \\
\hline Sweden & 2301.15 & 2486.74 & 7.46 & 1.08 & Democratic Republic of the Congo & 20.43 & 71.49 & 71.42 & 3.50 \\
\hline Kuwait & 1417.25 & 1928.99 & 26.53 & 1.36 & Rwanda & 15.73 & 68.38 & 77.00 & 4.35 \\
\hline Viet Nam & 1431.22 & 1696.13 & 15.62 & 1.19 & El Salvador & 26.10 & 68.00 & 61.61 & 2.60 \\
\hline Philippines & 713.72 & 1530.93 & 53.38 & 2.15 & Panama & 19.76 & 65.73 & 69.94 & 3.33 \\
\hline Austria & 1062.38 & 1119.73 & 5.12 & 1.05 & Burkina Faso & 36.31 & 50.82 & 28.55 & 1.40 \\
\hline Norway & 916.46 & 1093.15 & 16.16 & 1.19 & Mali & 46.24 & 50.01 & 7.52 & 1.08 \\
\hline Greece & 641.81 & 1080.36 & 40.59 & 1.68 & Honduras & 47.39 & 48.39 & 2.06 & 1.02 \\
\hline Myanmar & 927.62 & 1050.77 & 11.72 & 1.13 & Bolivia & 10.14 & 47.73 & 78.76 & 4.71 \\
\hline Kenya & 891.60 & 913.40 & 2.39 & 1.02 & Lesotho & 19.62 & 44.62 & 56.02 & 2.27 \\
\hline Finland & 864.57 & 886.45 & 2.47 & 1.03 & Niger & 33.44 & 38.36 & 12.83 & 1.15 \\
\hline Portugal & 483.86 & 605.30 & 20.06 & 1.25 & Barbados & 6.13 & 36.43 & 83.17 & 5.94 \\
\hline Hungary & 387.65 & 581.32 & 33.32 & 1.50 & Seychelles & 17.71 & 35.44 & 50.03 & 2.00 \\
\hline Iraq & 229.59 & 508.13 & 54.82 & 2.21 & Haiti & 22.65 & 31.67 & 28.50 & 1.40 \\
\hline
\end{tabular}


Table 3. Countries with Potential for Expansion of Trade(Continued)

\begin{tabular}{|c|c|c|c|c|c|c|c|c|c|}
\hline \multirow[t]{2}{*}{ Country } & $\begin{array}{l}\text { Actual trade } \\
\text { (A) }\end{array}$ & $\begin{array}{l}\text { Potential } \\
\text { trade }(\mathrm{P})\end{array}$ & Gap $^{* *}$ & $\mathrm{P} / \mathrm{A}^{\#}$ & \multirow[t]{2}{*}{ Country } & $\begin{array}{l}\text { Actual trade } \\
\text { (A) }{ }^{*}\end{array}$ & $\begin{array}{l}\text { Potential trade } \\
\text { (P) }\end{array}$ & $\mathrm{Gap}^{* *}$ & $\mathrm{P} / \mathrm{A}^{\#}$ \\
\hline & \multicolumn{2}{|c|}{ (US\$ million) } & $(\%)$ & & & \multicolumn{2}{|c|}{ (US\$ million) } & $(\%)$ & \\
\hline Algeria & 433.55 & 472.98 & 8.34 & 1.09 & Central African Republic & 2.42 & 22.95 & 89.47 & 9.50 \\
\hline Croatia & 106.15 & 309.24 & 65.67 & 2.91 & Tonga & 0.91 & 3.62 & 74.91 & 3.99 \\
\hline Belarus & 185.87 & 288.79 & 35.64 & 1.55 & Total (113) (US\$ billion) & 296.11 & 371.67 & & \\
\hline Lebanon & 136.60 & 379.94 & 64.05 & 2.78 & Samoa & 0.59 & 10.76 & 94.55 & 18.34 \\
\hline Slovakia & 144.22 & 372.89 & 61.32 & 2.59 & Comoros & 8.39 & 10.54 & 20.42 & 1.26 \\
\hline Azerbaijan & 224.88 & 345.06 & 34.83 & 1.53 & Dominica & 3.94 & 7.32 & 46.14 & 1.86 \\
\hline Libyan Arab Jamahiriya & 211.49 & 328.81 & 35.68 & 1.55 & Solomon islands & 3.66 & 6.11 & 40.15 & 1.67 \\
\hline
\end{tabular}

Notes: *Actual trade for 2007, taken from International Monetary Fund (2009a).

** Gap between potential and existing trade as a proportion of potential.

\# $\mathrm{P} / \mathrm{A}>1$ means potential of expansion of trade (see Batra, 2004). 
Table 4. Countries with which India Exceeded Trade Potential

\begin{tabular}{|c|c|c|c|c|}
\hline \multirow{2}{*}{ Country } & Actual trade $(\mathrm{A})^{*}$ & Potential trade $(\mathrm{P})$ & \multirow{2}{*}{$\begin{array}{c}\text { Gap }^{* *} \\
(\%)\end{array}$} & \multirow[t]{2}{*}{$\mathrm{P} / \mathrm{A}^{\#}$} \\
\hline & \multicolumn{2}{|c|}{ (US\$ million) } & & \\
\hline Belgium & 12330.38 & 12160.20 & -1.40 & 0.99 \\
\hline Switzerland & 2830.28 & 2550.79 & -10.96 & 0.90 \\
\hline Mexico & 2357.18 & 2055.62 & -14.67 & 0.87 \\
\hline Egypt & 1243.93 & 1097.59 & -13.33 & 0.88 \\
\hline Denmark & 967.41 & 951.48 & -1.67 & 0.98 \\
\hline Qatar & 2716.88 & 900.07 & -201.85 & 0.33 \\
\hline Nigeria & 1446.27 & 812.53 & -77.99 & 0.56 \\
\hline Oman & 892.02 & 760.73 & -17.26 & 0.85 \\
\hline Romania & 819.45 & 729.30 & -12.36 & 0.89 \\
\hline Ukraine & 1455.91 & 674.31 & -115.91 & 0.46 \\
\hline Czech Republic & 835.81 & 648.79 & -28.83 & 0.78 \\
\hline Mauritius & 755.91 & 615.37 & -22.84 & 0.81 \\
\hline New Zealand & 477.11 & 472.89 & -0.89 & 0.99 \\
\hline Bahrain & 540.09 & 346.24 & -55.99 & 0.64 \\
\hline Colombia & 517.16 & 337.72 & -53.14 & 0.65 \\
\hline Syrian Arab Republic & 419.03 & 318.36 & -31.62 & 0.76 \\
\hline Sudan & 514.90 & 297.96 & -72.81 & 0.58 \\
\hline Jordan & 779.95 & 286.15 & -172.57 & 0.37 \\
\hline Morocco & 823.00 & 283.79 & -190.00 & 0.34 \\
\hline Bhutan & 275.92 & 249.96 & -10.38 & 0.91 \\
\hline Yemen & 435.84 & 215.62 & -102.13 & 0.49 \\
\hline Tunisia & 303.75 & 199.94 & -51.92 & 0.66 \\
\hline Peru & 330.56 & 198.26 & -66.73 & 0.60 \\
\hline Zambia & 207.16 & 138.12 & -49.99 & 0.67 \\
\hline United Republic of Tanzania & 530.49 & 128.34 & -313.35 & 0.24 \\
\hline Ecuador & 120.50 & 114.25 & -5.47 & 0.95 \\
\hline Côte d'Ivoire & 271.67 & 101.47 & -167.72 & 0.37 \\
\hline Maldives & 98.07 & 85.93 & -14.12 & 0.88 \\
\hline Costa Rica & 81.08 & 80.34 & -0.92 & 0.99 \\
\hline Papua New Guinea & 126.28 & 80.15 & -57.56 & 0.63 \\
\hline Gabon & 87.14 & 77.04 & -13.10 & 0.88 \\
\hline Madagascar & 90.49 & 67.90 & -33.27 & 0.75 \\
\hline Malawi & 76.12 & 65.81 & -15.67 & 0.86 \\
\hline Senegal & 207.86 & 64.14 & -224.09 & 0.31 \\
\hline Mozambique & 145.18 & 60.70 & -139.19 & 0.42 \\
\hline Democratic Rep. of the Congo & 215.71 & 59.53 & -262.35 & 0.28 \\
\hline Benin & 269.11 & 44.75 & -501.36 & 0.17 \\
\hline
\end{tabular}


Table 4. Countries with which India Exceeded Trade Potential(Continued)

\begin{tabular}{|c|c|c|c|c|}
\hline \multirow{2}{*}{ Country } & Actual trade $(\mathrm{A})^{*}$ & Potential trade $(\mathrm{P})$ & Gap $^{* *}$ & $\mathrm{P} / \mathrm{A}^{7}$ \\
\hline & \multicolumn{2}{|c|}{ (US\$ million) } & \multicolumn{2}{|l|}{$(\%)$} \\
\hline Swaziland & 42.37 & 40.43 & -4.82 & 0.95 \\
\hline Fiji & 45.27 & 39.54 & -14.49 & 0.87 \\
\hline Guinea & 117.78 & 31.76 & -270.84 & 0.27 \\
\hline Sierra Leone & 32.43 & 28.90 & -12.19 & 0.89 \\
\hline Togo & 321.58 & 25.43 & -1164.62 & 0.08 \\
\hline Mauritania & 62.88 & 25.14 & -150.13 & 0.40 \\
\hline Djibouti & 319.49 & 21.32 & -1398.87 & 0.07 \\
\hline Suriname & 32.41 & 16.76 & -93.39 & 0.52 \\
\hline Burundi & 16.72 & 16.59 & -0.80 & 0.99 \\
\hline Liberia & 61.27 & 16.56 & -269.90 & 0.27 \\
\hline Guyana & 43.03 & 15.87 & -171.15 & 0.37 \\
\hline Gambia & 45.03 & 14.99 & -200.41 & 0.33 \\
\hline Guinea-Bissau & 138.92 & 6.12 & -2168.32 & 0.04 \\
\hline total $(50)$ & 37.87 & 28.63 & & \\
\hline
\end{tabular}

Notes: *Actual trade for 2007, taken from International Monetary Fund (2009a).

** Gap - between potential and existing trade as a proportion of potential.

\# $\mathrm{P} / \mathrm{A}<1$ means exceeded trade potential (see Batra, 2004).

Asia (e.g., Japan) as well as with developing countries in Asia such as the Republic of Korea, Thailand and Sri Lanka.

Table 4 presents the list of countries with which India has already exceeded its trade potential. Most of the countries in this group are smaller economies in terms of economic size and geographical area. Contrary to popular belief, India's trade with South Asian countries such as Bhutan and Maldives has exceeded potential by smaller margins as per the estimates given in this paper. India's trade in South Asia is well below that with other regions. When comparing the results in Tables 3 and 4 , it can be seen that India offers relatively modest trade expansion potential with slow growth in the post-crisis period.

Tables 5 and 6 present India's trade potential up until 2014, using the new GDP series of the International Monetary Fund (2009b). Apparently, the pre-crisis potential is likely to disappear mainly due to the ongoing global meltdown in general, and the contraction of GDP in advanced economies in particular. While deceleration in India's trade growth with developed countries is obvious, trade between India and developing countries and least developed countries will grow albeit at a slower pace. For example, India's trade with China has potential for expansion from the present US\$ 40 billion to US\$ 68 billion in 2014, and is 
Table 5. Countries with Potential for Expansion of Trade in Post-crisis Period

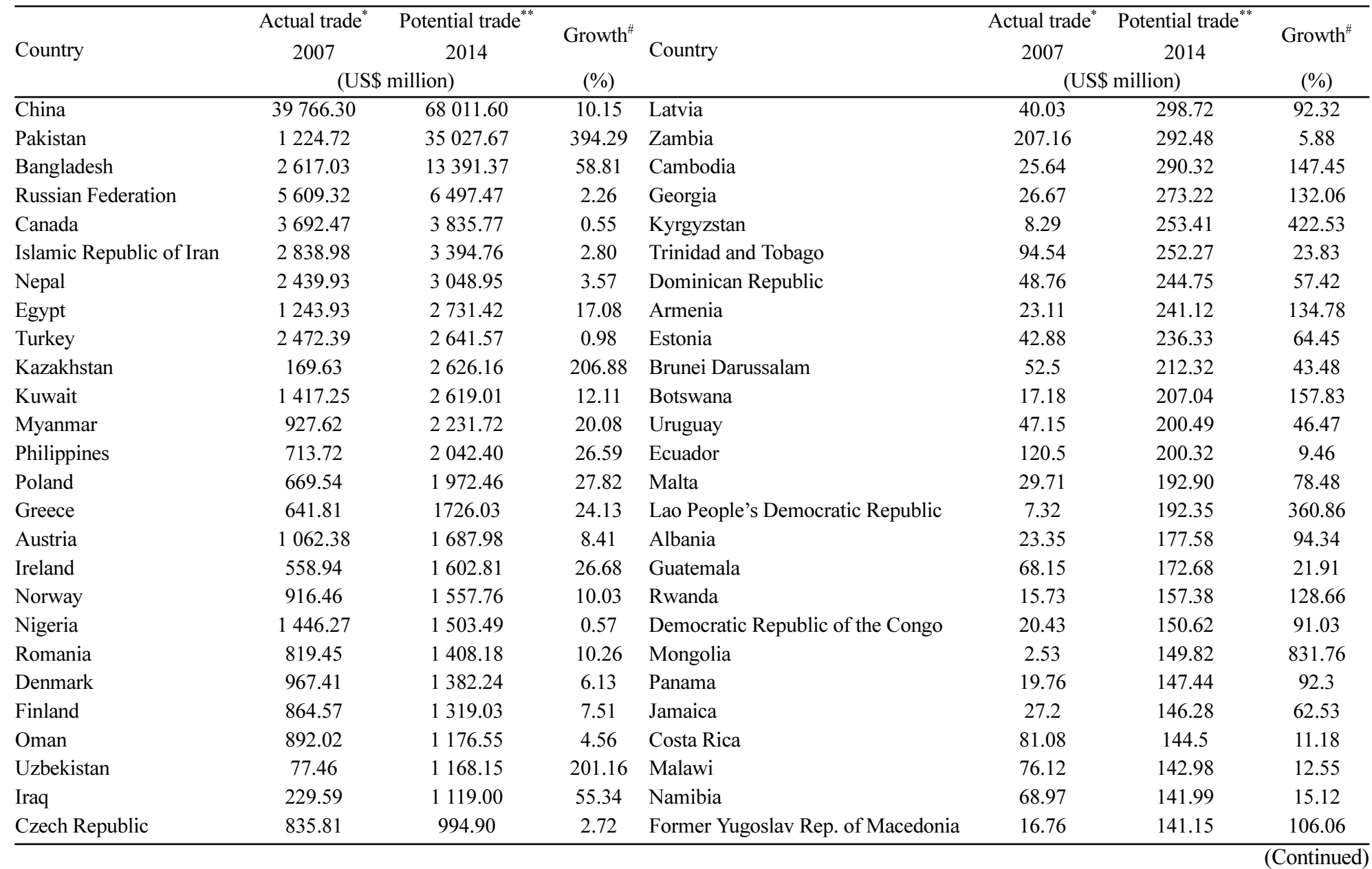


Table 5. Countries with Potential for Expansion of Trade in Post-crisis Period(Continued)

\begin{tabular}{|c|c|c|c|c|c|c|c|}
\hline Country & $\begin{array}{c}\text { Actual trade } \\
2007\end{array}$ & $\begin{array}{c}\text { Potential trade }^{* * *} \\
2014\end{array}$ & $\begin{array}{c}\text { Growth }^{\#} \\
(\%)\end{array}$ & Country & \multicolumn{2}{|c|}{ Actual trade ${ }^{*}$ Potential trade ${ }^{* *}$} & $\begin{array}{c}\text { Growth }^{\dagger} \\
(\%)\end{array}$ \\
\hline Hungary & 387.65 & 980.06 & 21.83 & Papua New Guinea & 126.28 & 140.39 & 1.6 \\
\hline Portugal & 483.86 & 865.25 & 11.26 & Iceland & 25.68 & 127.76 & 56.77 \\
\hline Algeria & 433.55 & 830.69 & 13.09 & El Salvador & 26.1 & 121.39 & 52.14 \\
\hline Azerbaijan & 224.88 & 767.74 & 34.49 & Equatorial Guinea & 9.21 & 119.86 & 171.9 \\
\hline Slovakia & 144.22 & 713.24 & 56.36 & Bolivia & 10.14 & 108.75 & 138.98 \\
\hline Venezuela & 226.07 & 677.83 & 28.55 & Honduras & 47.39 & 107.37 & 18.08 \\
\hline Sudan & 514.9 & 676.42 & 4.48 & Burkina Faso & 36.31 & 100.53 & 25.26 \\
\hline Libyan Arab Jamahiriya & 211.49 & 664.11 & 30.57 & Mali & 46.24 & 97.71 & 15.9 \\
\hline Belarus & 185.87 & 641.08 & 34.99 & Chad & 6.78 & 96.77 & 189.68 \\
\hline Yemen & 435.84 & 561.47 & 4.12 & Bahamas & 30.32 & 91.37 & 28.77 \\
\hline Croatia & 106.15 & 511.53 & 54.56 & Haiti & 22.65 & 54.87 & 20.33 \\
\hline Slovenia & 170.07 & 443.63 & 22.98 & Seychelles & 17.71 & 51.42 & 27.2 \\
\hline Ethiopia & 119.17 & 442.99 & 38.82 & Nicaragua & 10.59 & 50.85 & 54.34 \\
\hline Lithuania & 42.73 & 410.31 & 122.89 & Lesotho & 19.62 & 50.03 & 22.14 \\
\hline Peru & 330.56 & 385.76 & 2.39 & Swaziland & 42.37 & 42.88 & 0.17 \\
\hline Uganda & 139.49 & 382.62 & 24.9 & Central African Republic & 2.42 & 42.86 & 239.08 \\
\hline Tajikistan & 7.84 & 369.32 & 658.87 & Suriname & 32.41 & 38.85 & 2.84 \\
\hline Tunisia & 303.75 & 358.64 & 2.58 & Burundi & 16.72 & 34.05 & 14.81 \\
\hline Cameroon & 71.37 & 341.23 & 54.02 & Antigua and Barbuda & 1.75 & 30.21 & 231.83 \\
\hline Cyprus & 50.88 & 332.64 & 79.12 & Belize & 3.48 & 30.12 & 109.45 \\
\hline Total (108) & 84.29 & 190.70 & & & & & \\
\hline
\end{tabular}


Table 6. Countries with Potential for Trade Contraction in the Post-crisis Period

\begin{tabular}{|c|c|c|c|}
\hline \multirow{3}{*}{ Countries } & Actual Trade ${ }^{*}$ & Potential Trade ${ }^{* *}$ & \multirow{2}{*}{ Growth } \\
\hline & 2007 & 2014 & \\
\hline & \multicolumn{2}{|c|}{ (US\$ million) } & $(\%)$ \\
\hline United States & 42182.12 & 20435.79 & -7.36 \\
\hline Japan & 10562.88 & 9429.33 & -1.53 \\
\hline United Kingdom & 13154.69 & 8445.12 & -5.11 \\
\hline Germany & 16470.92 & 6401.37 & -8.73 \\
\hline Republic of Korea & 11464.06 & 5863.69 & -6.98 \\
\hline France & 7997.92 & 5672.88 & -4.15 \\
\hline Italy & 8782.62 & 5075.76 & -6.03 \\
\hline Saudi Arabia & 5064.88 & 3583.24 & -4.18 \\
\hline Spain & 3690.93 & 3361.12 & -1.28 \\
\hline United Arab Emirates & 19908.49 & 2981.43 & -12.15 \\
\hline Hong Kong, China & 10488.01 & 2895.82 & -10.34 \\
\hline Australia & 9777.30 & 2823.10 & -10.16 \\
\hline Thailand & 4826.00 & 2662.45 & -6.40 \\
\hline Indonesia & 6901.58 & 2642.56 & -8.82 \\
\hline Singapore & 16335.79 & 2560.04 & -12.05 \\
\hline Israel & 3310.07 & 2550.92 & -3.28 \\
\hline Netherlands & 5017.36 & 2476.38 & -7.23 \\
\hline Brazil & 3218.57 & 2132.93 & -4.82 \\
\hline Qatar & 2716.88 & 1867.85 & -4.46 \\
\hline Malaysia & 8345.48 & 1846.20 & -11.13 \\
\hline Sweden & 2301.15 & 1791.14 & -3.17 \\
\hline Belgium & 12330.38 & 1713.40 & -12.30 \\
\hline Switzerland & 2830.28 & 1669.03 & -5.86 \\
\hline South Africa & 3262.12 & 1600.73 & -7.28 \\
\hline Mexico & 2357.18 & 1558.87 & -4.84 \\
\hline Viet Nam & 1431.22 & 1250.19 & -1.81 \\
\hline Ukraine & 1455.91 & 1159.42 & -2.91 \\
\hline Sri Lanka & 2939.67 & 748.35 & -10.65 \\
\hline Kenya & 891.60 & 727.38 & -2.63 \\
\hline Argentina & 1293.53 & 706.53 & -6.48 \\
\hline Jordan & 779.95 & 607.25 & -3.16 \\
\hline Morocco & 823.00 & 559.16 & -4.58 \\
\hline Bahrain & 540.09 & 459.08 & -2.14 \\
\hline Chile & 2621.62 & 419.60 & -12.00 \\
\hline United Rep. of Tanzania & 530.49 & 283.58 & -6.65 \\
\hline Mauritius & 755.91 & 226.98 & -10.00 \\
\hline Côte d'Ivoire & 271.67 & 195.35 & -4.01 \\
\hline
\end{tabular}


Table 6. Countries with Potential for Trade Contraction in the Post-crisis Period(Continued)

\begin{tabular}{lccc}
\hline \multirow{2}{*}{ Countries } & Actual Trade $^{*}$ & Potential Trade $^{* *}$ & $\begin{array}{c}\text { Growth }^{\#} \\
\text { ny }\end{array}$ \\
\cline { 2 - 3 } Mozambique & 2007 & 2014 & -2.20 \\
Senegal & 145.18 & 122.81 & -6.15 \\
Democratic Rep. of the Congo & 207.86 & 118.42 & -7.41 \\
Benin & 215.71 & 103.87 & -9.06 \\
Maldives & 269.11 & 98.45 & -2.89 \\
Mauritania & 98.07 & 78.26 & -0.97 \\
Guinea & 62.88 & 58.60 & -7.23 \\
Djibouti & 117.78 & 58.19 & -12.10 \\
Togo & 319.49 & 48.93 & -12.31 \\
Liberia & 321.58 & 44.42 & -4.83 \\
Guyana & 61.27 & 40.54 & -3.95 \\
Gambia, & 43.03 & 31.14 & -5.71 \\
Guinea-Bissau & 45.03 & 27.02 & -13.13 \\
Total (50) & 138.92 & 11.26 & \\
\hline
\end{tabular}

Notes: *Actual trade for 2007, taken from International Monetary Fund, (2009a).

** Predicted based of GDP taken from International Monetary Fund, (2009b).

\# Average annual growth rate.

expected to grow by about $10 \%$ per annum until 2014 . The magnitude of trade potential is relatively high in adjacent countries such as those in South Asia (Pakistan and Bangladesh), Central Asia (Kazakhstan) and countries in Africa and Latin America. However, net gains for India will be still negative until 2014 due to contraction both in economic growth in developed countries and in slow global demand. As a result, the Gravity model estimates given in this paper indicate a scaling down of about $14.25 \%$ in India's trade potential, from US\$ 400.31 billion in the pre-crisis period to US\$343.28 billion in the post-crisis period, ceteris paribus. ${ }^{18}$

Estimates being robust, India's trade potential is therefore predicted for two scenarios: (a) pre-crisis, which is a sort of an optimal potential, and (b) post-crisis,

\footnotetext{
${ }^{18}$ This result must be interpreted cautiously. The trade potential has been estimated based on India's 168 partner countries (accounting for about $90 \%$ of total trade flow), whereas India traded with 235 countries in the case of exports and 229 countries in the case of imports in 2007/08.

${ }^{19}$ On 25 April 2009 the International Monetary Fund (2009b) released new estimates of GDP by country up until 2014. Taking those in bilateral pairs in equation (2) and multiplying them by estimated coefficients in table 3, India's trade potential can be estimated up until 2014 with the assumption that the dummies remain time-invariant.
} 
Table 7. Potential for Expansion of Trade with East Asia: Pre-crisis Scenario

\begin{tabular}{ccccc}
\hline Country & Actual trade $(\mathrm{A})^{*}$ & Potential trade $(\mathrm{P})$ & Gap $^{* *}$ & P/A $^{\#}$ \\
\hline ASEAN & 39.54 & 43.82 & 9.76 & 1.11 \\
ASEAN+3 & 111.82 & 133.98 & 16.54 & 1.20 \\
EAS (ASEAN+6) & 122.08 & 146.60 & 16.73 & 1.20 \\
\hline
\end{tabular}

Notes: *Actual trade for 2007, taken from International Monetary Fund (2009a).

${ }^{* *}$ Predicted based of GDP taken from International Monetary Fund (2009b).

\# Average annual growth rate.

Figure 6. India's Trade Potential with East Asia: Post-crisis Scenario

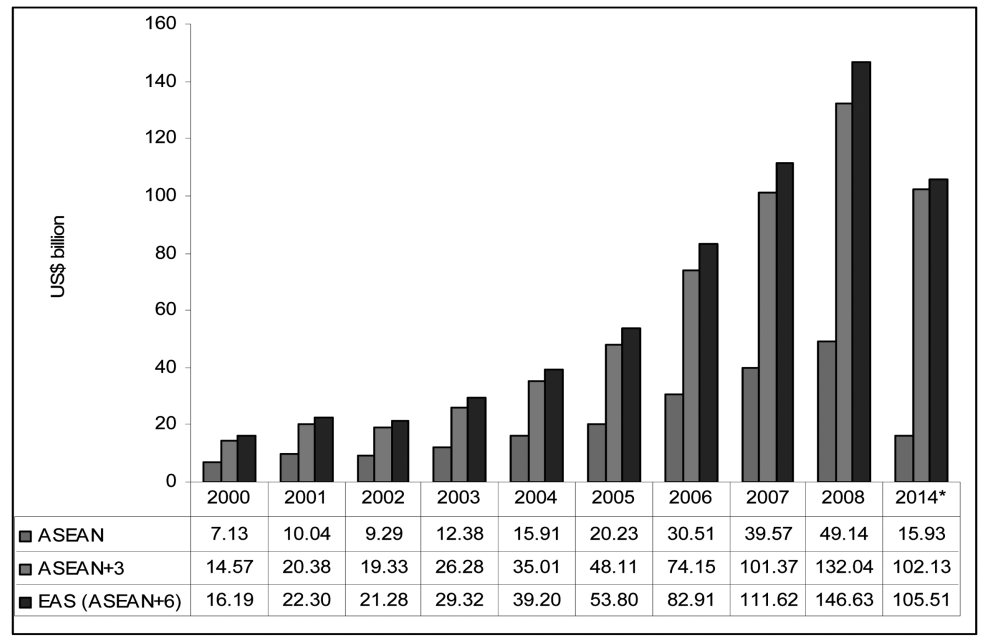

Note: *Potential trade (Gravity estimates), predicted following equation 2 based on GDP taken from International Monetary Fund (2009b). Data for 2000 to 2008 is actual.

using the International Monetary Fund's World Economic Outlook GDP up until 2014. ${ }^{19}$ For estimating trade potential, GLS was selected for two technical reasons: (a) the Hausman test rejects fixed effect (OLS) and selects random effect (GLS); and (b) GLS provides a higher R-squared. The gap between trade potential as predicted by the model and actual trade is then used to analyse the future direction of trade. The usual caveat is that the Gravity model accounts for an average $90 \%$ of India's trade flows covering 163 trade partners in calendar years. Trade potential would therefore certainly be lower than the actual trade in goods realized in India today.

Gravity model estimates show that $\mathrm{P} / \mathrm{A}$ ratios are greater than 1 in all three regional trading arrangements, namely, ASEAN, ASEAN+3 and ASEAN+6 (Table 7), thereby indicating India had high unrealized trade with East Asia in pre-crisis 
period. The gap between actual and potential trade becomes wider in cases of ASEAN+3 and EAS (ASEAN+6) arrangements. However, the scenario is likely to be reversed in the post-crisis period. The pre-crisis trade potential has been disappearing due to the contraction of output in advanced economies in general and world-wide trade downturn in particular. If the falling trends in output continue, the Gravity estimates show that India's trade with East Asia will obviously decrease, thus suggesting a simultaneous fall in trade potential with EAS (ASEAN+6) from US\$ 147 billion in 2007 to US\$ 106 billion in 2014 (Figure 6). Nevertheless, India's trade with East Asia will grow albeit at a slower pace.

\section{Unlocking India's Trade Potential: Influencing Factors and Trade Remedies}

The Gravity model indicates that the slowdown in global demand brought on by the ongoing economic downturn will decelerate India's trade in coming years. Actual outcome is even more disappointing. Indian exports in March 2009 slowed by $33.3 \%$, compared with March $2008,{ }^{20}$ and the falling trends continue till September 2009. Given the slowdown in global demand, the Government of India has an important role to play in enhancing the country's exports. While dealing with some important "policy" and "non-policy" barriers to India's exports, particularly with East Asia, this section also discusses the important factors that will play a key role in enhancing India's exports amidst the financial crisis.

The analysis follows panel data modelling of India's exports. Table 8 reports OLS and GLS estimates of equation (7). The tariff and transaction cost variables are expected to be negatively correlated with the volume of exports. Variables being in natural logarithms, estimated coefficients show CES elasticity. The elasticity is useful as an indicator of the effect of trade barriers on trade volumes. Importantly, the model performs well, as most of the coefficients are significant and the variables do have the expected signs.

The econometric evidence appears to strengthen the existing linkage of trade costs and trade flows; the higher the tariff and trade transaction costs between each pair of partners, the less they trade. In this case, it is seen that a $10 \%$ fall in trade partner's tariffs and trade transaction costs has the effect of increasing India's

${ }^{20}$ See the press release, 1 May 2009 (F. No. 1(5)/2008-EPL), Government of India, Ministry of Commerce and Industry, Department of Commerce, Economic Division, New Delhi. 
exports by about $3 \%$ and $2 \%$, respectively, while their combined effect on India's exports is about $4 \%$ (model 4 ). Although as per the specification tests, the random effect has turned out to be the appropriate model, the fixed effects estimation has been run as well and compared between the OLS and GLS R ${ }^{2}{ }^{21}$ An improvement in overall goodness of fit of the GLS estimation (75.6\% in model 3) can be seen when compared with OLS (57.3\% in model 1). The REM reports values of Wald $\chi^{2}$. The reported $\chi^{2}$ value of 695.14 in model 3 is highly significant with the

Table 8. Non-linear Least Square Estimates

\begin{tabular}{|c|c|c|c|c|}
\hline \multicolumn{3}{|c|}{ Dependent Variable: Log of Exports } & \multicolumn{2}{|c|}{ Panel: 1995 to 2007} \\
\hline & \multicolumn{2}{|c|}{$\mathrm{OLS}^{1}$} & \multicolumn{2}{|c|}{$\mathrm{GLS}^{2}$} \\
\hline & Model 1 & Model 2 & Model 3 & Model 4 \\
\hline \multirow{2}{*}{ Exporter GDP } & $4.621^{* *}$ & $4.320^{* *}$ & $3.697^{* *}$ & $3.428^{* *}$ \\
\hline & $(20.031)$ & $(21.153)$ & $(5.008)$ & $(4.631)$ \\
\hline \multirow{2}{*}{ Importer GDP } & $0.442^{* *}$ & $0.444^{* *}$ & $0.2894^{* *}$ & $0.283^{* *}$ \\
\hline & $(12.471)$ & $(14.123)$ & $(3.862)$ & $(3.574)$ \\
\hline \multirow{2}{*}{ Trade transaction costs } & $-0.165^{* *}$ & & $-0.168^{* *}$ & \\
\hline & $(-4.121)$ & & $(-2.978)$ & \\
\hline \multirow{2}{*}{ Tariff } & $-0.190^{* *}$ & & $-0.268^{* *}$ & \\
\hline & $(-3.243)$ & & $(-3.570)$ & \\
\hline \multirow{2}{*}{$\begin{array}{l}\text { Trade transaction costs }+ \text { Tariff } \\
\text { (TTcT) }\end{array}$} & & $-0.341^{* *}$ & & $-0.368^{* *}$ \\
\hline & & $(-5.379)$ & & $(-3.578)$ \\
\hline \multirow{2}{*}{ Distance } & $-0.593^{* *}$ & $-0.598^{* *}$ & -0.278 & -0.325 \\
\hline & $(-5.788)$ & $(-5.952)$ & $(-1.145)$ & $(-1.237)$ \\
\hline \multirow{2}{*}{ Adjacency } & $-0.775^{* *}$ & $-0.810^{* *}$ & -1.032 & $-1.372^{*}$ \\
\hline & $(3.439)$ & $(4.008)$ & $(1.897)$ & $(2.334)$ \\
\hline \multirow{2}{*}{ Language } & $0.647^{* *}$ & $0.651^{* *}$ & $0.672^{* *}$ & $0.739^{* *}$ \\
\hline & (7.382) & (7.358) & (2.617) & $(2.728)$ \\
\hline \multirow{2}{*}{ RTA } & $0.553^{* *}$ & $0.568^{* *}$ & $0.360^{* *}$ & $0.381^{* *}$ \\
\hline & (3.719) & $(4.011)$ & $(3.646)$ & $(3.732)$ \\
\hline Observations & 370 & 370 & 370 & 370 \\
\hline $\mathrm{R}^{2}$ & 0.573 & 0.582 & 0.756 & 0.749 \\
\hline Wald $\chi^{2}$ & & & 695.14 & 691.93 \\
\hline Prob $>\chi^{2}$ & & & 0.000 & 0.000 \\
\hline
\end{tabular}

Notes: 1. Fixed effect model. 2. Random effect model. Selection of random effect over fixed effect was based on the Hausman test. Robust $t$-statistics in parentheses for OLS and z-statistics for GLS ${ }^{* *}$ $p<0.01,{ }^{*} p<0.05$. Country-pair effects (38) are included in the model. All variables except dummies are taken in log. All results are checked for robust standard errors and heteroscedasticity.

\footnotetext{
${ }^{22}$ See Appendix E for results of 2SLS.

${ }^{21}$ The selection of the random effect model over fixed effect was made through the Hausman test. See Appendix D.
} 
probability $>\chi^{2}(=0.0000)$. Taken jointly, this model shows an almost perfect fit. To solve the possibility of endogeneity of economic size, two-stage simultaneous equation modelling (2SLS) has been employed, using an instrument such as population. The use of the 2SLS technique does not alter the coefficients of any of the variables to any significant extent. ${ }^{22}$

The estimated model explains about $75 \%$ of the variations in the direction of trade flows. The most interesting result is the strong influence that changes in tariff and transaction costs had on changes in trade; the higher the barriers between each pair of partners, the less they trade. Their combined effect on trade flows is thus substantial. The estimates also appear to show that the size of the effects does not vary widely.

The estimated models also indicate that tariffs do influence trade flow since all estimated coefficients appear as statistically significant. The significance of tariffs in the Gravity model is the fact that tariff liberalization is not yet dead, and that further tariff cuts by partner countries would enhance India's exports. From the estimated elasticities and their significance level, it can be concluded that both tariffs and transaction costs are important determinants in enhancing India's exports.

All the dummies such as language, adjacency and RTA appear with the correct sign and are significant. India will continue to trade more with countries having language similarity and which are geographically close. The significant RTA dummy clearly indicates that free trade agreements (regional or otherwise), as long as they are supported by tariff liberalization and trade facilitation, increase the probability of India's exports. These are the alternative measures for sustaining the growth of exports, instead of reverting to protecting domestic markets. Finally, the findings detailed in this paper provide following important policy lessons.

First, international trade has a key role to play in the economic recovery during the current global crisis, provided it is complemented by trade liberalization and trade facilitation. In this analysis, tariffs have come out as statistically significant trade barriers, and have a strong negative effect on trade flows. Trade liberalization

\footnotetext{
${ }^{23}$ There has been a marked increase in protectionist pressures globally since September 2008. The World Trade Organization (2009b) and ESCAP (2009) reported that about 47 protectionist trade measures have been implemented since the beginning of the current financial crisis. Many Asian and Pacific region countries have enacted protectionist measures in recent months, in the form of both increased import tariffs and non-tariff measures (including administrative measures, subsidies and anti-dumping measures). Protectionist measures to safeguard national industries and jobs will also reduce the overall transparency of policies and markets, and lead to more restricted trade worldwide.
} 
initiatives virtually stopped for the past few years due mainly to the stagnation of the WTO Doha Round. Protectionism is on the rise worldwide amidst the current global economic and financial crisis. ${ }^{23}$ A return to protectionism would therefore exacerbate the current crisis and further slow down exports.

Second, trade transaction costs have an equally strong catalytic role in enhancing India's trade. This aspect appears robust and statistically significant in all the models in this analysis. Therefore, India and its partner countries need to take serious measures aimed at reducing "behind the border" and "at the border" costs of exports, which can be expected to have a significant impact on India's trade. Trade facilitation is an essential measure to decrease the cost and time required for trade across borders. A surge in trade transaction barriers at this particular time could take a very long time to clean up and would adversely affect world trade for years to come. This is an opportune time for countries to aptly choose appropriate trade facilitation measures that will not only have strong multiplier effects on a country's exports but will also raise its competitiveness in the short term.

Third, while trade liberalization is important, it sometimes is not adequate for enhancing a country's trade. Trade facilitation can complement that effort. The Gravity results show that trade liberalization coupled with trade facilitation can increase India's exports by an average 4\%, which could be a reasonably good gain during the ongoing global economic and financial crisis.

Fourth, multilateralizing RTAs would generate more exports for India. India needs to expand the geographic reach of its RTAs. In other words, the multilateral trading regime of GATT/WTO is the best solution to the ongoing crisis because it has so far been the most successful attempt since the Second World War at achieving a transparent, equitable and efficient rules-based worldwide trading system.

Finally, if trade costs are improved, India's economic engagement with East Asia would continue to grow. Undoubtedly, India's growing association with East Asia will lead to strengthen the regional demand. However, both East Asia and India must address the structural constraints that are holding back the integration process. An integrated Asia is the key for a sustained recovery from the ongoing global economic and financial crisis.

\section{Conclusion}

This paper estimates the trade potential for India, using the augmented Gravity model and then attempts to determine the importance of trade remedies. The model 
fits the data relatively well and demonstrates that the selection of equation is an important component of the Gravity equation that should be taken into account when estimating trade flows. Based on time series panel data, the Gravity model used in this paper is the first-ever attempt to estimate India's trade potential in the pre- and post- crisis period. The estimates of India's global trade potential reveal that the magnitude of India's trade potential is at a maximum in the Asian and Pacific region, followed by Africa and Latin America. Potential for expansion of trade in the post-crisis period is highest with countries such as China. However, India's trade has remained unrealized with a large part of the world, which presents further opportunities for expanding trade, despite slowdown in global demand. Thus, controlling for country level heterogeneity, estimated results in the study show India has high trade potential with Asian countries.

The significance of tariffs in the Gravity model is the fact that tariff liberalization is not yet dead, and that further tariff cuts by partner countries would enhance India's exports. There is a strong complementary role, as the findings of this paper indicate, for tariff liberalization and trade facilitation, which taken together can help build export momentum in the post-crisis period.

This paper suggests that efforts to promote regional and global integration need to address policy reform across a number of areas, and should not be limited to traditional trade policy measures such as tariffs. Thus, trade facilitation has an important complementary role to play, in the broad sense, in enhancing India's trade. This also is an example for all other countries facing the pressure of the ongoing global economic and financial crisis.

The study is not beyond limitations. The analysis of the trade potential and the effect of the crisis is driven by projected reductions in income growth, but it assumes that trade structure stays same. Endogenous responses to the crisis such as possible greater reliance on regional markets were not covered in this study, which may be dealt in future studies. Finally, the actual measures of trade costs in India and partner countries may be used in order to better estimate transport costs between the countries.

\section{Acknowledgment}

This paper is an outcome of the UNESCAP/ARTNeT/RIS Gravity Modelling Initiative on "Behind the Border" Factors Affecting Trade (2008-2009). Author is also grateful to one anonymous referee of the journal and Mia Mikic, Ben 
Shepherd, Yann Duval, Aniruddha Bagchi, and Priyadarshi Dash for their useful comments on an earlier version of this paper. Views expressed by the author are his personal. Usual disclaimers apply.

Received 15 December 2009, Revised 23 January 2010, Accepted 29 January 2010

\section{Appendix}

Appendix A. List of Data and Sources

\begin{tabular}{|c|c|c|c|}
\hline Outline & Classification & Particular & Sources \\
\hline Trade in goods & Aggregate total & $\begin{array}{l}\text { Trade in goods taken in } \\
\text { US dollars, converted } \\
\text { at constant price }\end{array}$ & $\begin{array}{l}\text { United Nations Com- } \\
\text { modity Statistics (UN } \\
\text { COMTRADE) }\end{array}$ \\
\hline Tariff in goods & Aggregate total & $\begin{array}{l}\text { Tariff represented by } \\
\text { weighted average tariff } \\
\text { (\%) }\end{array}$ & $\begin{array}{l}\text { World Integrated Trade } \\
\text { Solution Database, } \\
\text { World Bank and } \\
\text { UNCTAD }\end{array}$ \\
\hline Economic size & GDP, population & $\begin{array}{l}\text { GDP taken in US\$, } \\
\text { converted in constant } \\
\text { price }\end{array}$ & $\begin{array}{l}\text { World Development } \\
\text { Indicators Database, } \\
\text { World Bank; and World } \\
\text { Economic Outlook } \\
\text { Database, International } \\
\text { Monetary Fund }\end{array}$ \\
\hline Bilateral distance & $\begin{array}{l}\text { Capital to capital } \\
\text { distance }\end{array}$ & $\begin{array}{l}\text { Surface distance } \\
\text { taken in } \mathrm{km} .\end{array}$ & $\begin{array}{l}\text { CEPII database (French } \\
\text { Centre for Research and } \\
\text { Studies on the World } \\
\text { Economy) }\end{array}$ \\
\hline & Language & Binary variable ( 1 or 0$)$ & CEPII database \\
\hline & Adjacency/border & Binary variable ( 1 or 0$)$ & CEPII database \\
\hline Dummies & RTA/FTA & $\begin{array}{l}\text { Binary variable } \\
(1 \text { or } 0)\end{array}$ & $\begin{array}{l}\text { Asia-Pacific Trade and } \\
\text { Investment Agreement } \\
\text { Database (APTIAD), } \\
\text { ESCAP; Asia Regional } \\
\text { Integration Centre and } \\
\text { ADB }\end{array}$ \\
\hline
\end{tabular}


Appendix B. Correlation Matrix

\begin{tabular}{cccccccccc}
\hline & $\mathrm{T}_{i j}$ & $\mathrm{Y}_{i}$ & $\mathrm{Y}_{j}$ & $\mathrm{Pop}_{i}$ & $\mathrm{Pop}_{j}$ & $\mathrm{D}_{i j}$ & $\mathrm{ADJ}_{i j}$ & $\operatorname{Lan}_{i j}$ & $\mathrm{RTA}_{i j}$ \\
\hline $\mathrm{T}_{i j}$ & 1 & & & & & & & & \\
$\mathrm{Y}_{i}$ & $0.2465^{*}$ & 1 & & & & & & & \\
$\mathrm{Y}_{j}$ & $0.6862^{*}$ & $0.1169^{*}$ & 1 & & & & & & \\
$\mathrm{Pop}_{i}$ & $0.2433^{*}$ & $0.9650^{*}$ & $0.1099^{*}$ & 1 & & & & & \\
$\mathrm{Pop}_{j}$ & $0.5805^{*}$ & 0.0288 & $0.6211^{*}$ & 0.0301 & 1 & & & & \\
$\mathrm{D}_{i j}$ & $-0.2359^{*}$ & 0.0000 & -0.0315 & 0.000 & $-0.1902^{*}$ & 1 & & & \\
$\mathrm{ADJ}_{i j}$ & $0.1575^{*}$ & 0.0000 & -0.0209 & 0.000 & $0.2103^{*}$ & $-0.4262^{*}$ & 1 & & \\
$\mathrm{Lan}_{i j}$ & 0.0235 & 0.0000 & $-0.0566^{*}$ & 0.000 & $-0.1555^{*}$ & $0.1572^{*}$ & 0.023 & 1 & \\
$\mathrm{RTA}_{i j}$ & $0.2708^{*}$ & $0.2184^{*}$ & $0.1121^{*}$ & $0.1995^{*}$ & $0.0730^{*}$ & $-0.3339^{*}$ & $0.4006^{*}$ & $0.0548^{*}$ & 1 \\
\hline
\end{tabular}

*Significant at the $5 \%$ level

Appendix C. Non-linear Regression: Alternative Estimates

\begin{tabular}{lcc}
\hline & MLE & FMLE \\
\hline Economic size $\left(\mathrm{GDP}_{i} * \mathrm{GDP}_{j}\right)$ & $0.919^{* *}$ & $0.919^{* * *}$ \\
& $(31.72)$ & $(0.029)$ \\
Distance $\left(\mathrm{D}_{i j}\right)$ & $-0.743^{* *}$ & $-0.744^{* * *}$ \\
& $(-3.527)$ & -0.211 \\
Adjacency $\left(\mathrm{ADJ}_{i j}\right)$ & 1.314 & $1.312^{*}$ \\
& $(1.797)$ & $(0.731)$ \\
Language $\left(\operatorname{Lang}_{i j}\right)$ & $0.578^{*}$ & $0.577^{* *}$ \\
& $(2.111)$ & $(0.274)$ \\
RTA $\left(\mathrm{RTA}_{i j}\right)$ & 0.177 & 0.177 \\
& $(1.486)$ & -0.119 \\
Constant & $-22.19^{* *}$ & $-16.35^{* * *}$ \\
Observations & $(-9.441)$ & $(-2.801)$ \\
Log likelihood & 2205 & 2205 \\
/sigma_u & -3419 & -3419 \\
/sigma_e & $1.552^{* *}$ & \\
rho & $(17.51)$ & \\
/mu & $0.997^{* *}$ & \\
/lnsigma2 & $(63.66)$ & \\
/ilgtgamma & 0.708 & \\
\hline
\end{tabular}

Notes: Robust $t$-statistics in parentheses. ${ }^{* * *} p<0.01,{ }^{* *} p<0.05,{ }^{*} p<0.1$. All variables except dummies are taken in log. 
Appendix D. Selection of Model: FEM vs. REM

\section{Model 3 (Table 3)}

$\mathrm{b}=$ consistent under Ho and Ha; obtained from xtreg

$\mathrm{B}=$ inconsistent under Ha, efficient under Ho; obtained from xtreg

Test: Ho: difference in coefficients not systematic

$\operatorname{chi} 2(6)=(b-B)^{\prime}\left[\left(V_{-} b-V \_B\right)^{\wedge}(-1)\right](b-B)=4.06$

Prob $>$ chi $2=0.6682$

(V_b-V_B is not positive definite)

Select Random effect

\section{Model 4 (Table 4)}

$\mathrm{b}=$ consistent under Ho and Ha; obtained from xtreg

$\mathrm{B}=$ inconsistent under Ha, efficient under Ho; obtained from xtreg

Test: Ho: difference in coefficients not systematic

$\operatorname{chi} 2(5)=(b-B)^{\prime}\left[\left(V_{-} b-V \_B\right)^{\wedge}(-1)\right](b-B)=0.7933$

Prob $>$ chi $2=0.6682$

Select Random effect

Appendix E. Regression Results: REM vs. 2SLS

\begin{tabular}{|c|c|c|}
\hline & REM & 2SLS \\
\hline Exporter GDP & $\begin{array}{l}1.755^{* * *} \\
(15.87)\end{array}$ & $\begin{array}{c}2.541^{* * *} \\
(4.718)\end{array}$ \\
\hline Importer GDP & $\begin{array}{l}0.0391^{* * *} \\
(3.027)\end{array}$ & $\begin{array}{l}0.0393^{* * *} \\
(2.957)\end{array}$ \\
\hline Exporter Population & & $\begin{array}{c}3.383 \\
(1.600)\end{array}$ \\
\hline Importer population & & $\begin{array}{c}0.168^{*} \\
(1.847)\end{array}$ \\
\hline Transaction costs & $\begin{array}{l}-0.0579^{* * *} \\
(-3.036)\end{array}$ & $\begin{array}{l}-0.0597^{* * *} \\
(-2.991)\end{array}$ \\
\hline Tariff & $\begin{array}{l}-0.255^{* * *} \\
(-3.372)\end{array}$ & $\begin{array}{l}-0.287^{* * *} \\
(-3.781)\end{array}$ \\
\hline Distance & $\begin{array}{c}-0.282 \\
(-1.177)\end{array}$ & $\begin{array}{l}-0.282 \\
(-1.177)\end{array}$ \\
\hline Adjacency & $\begin{array}{l}1.207^{* *} \\
(2.208)\end{array}$ & $\begin{array}{c}0.739^{*} \\
(1.870)\end{array}$ \\
\hline Language & $\begin{array}{l}0.728^{* * *} \\
(2.723)\end{array}$ & $\begin{array}{l}0.634^{* *} \\
(2.503)\end{array}$ \\
\hline RTA & $\begin{array}{l}0.368^{* * *} \\
(3.661)\end{array}$ & $\begin{array}{c}0.383^{* * *} \\
(3.921)\end{array}$ \\
\hline Observations & 370 & 370 \\
\hline R-squared & 0.7588 & 0.7593 \\
\hline Wald chi2 & 668.53 & 691.91 \\
\hline Prob $>$ chi 2 & 0.000 & 0.000 \\
\hline
\end{tabular}

Notes: Robust z-values are given in parentheses. All variables except dummies are taken in log. ${ }^{* * *} p<0.01,{ }^{* *} p<0.05 .{ }^{*} p<0.1$ Year effects (13) and country-pair effects (38) are included in the model. All results checked for robust standard errors and heteroscedasticity. 


\section{References}

Acharya, S.(2009), India and Global Crisis, Academic Foundation, New Delhi.

Anderson, J. E.(1979), “A Theoretical Foundation for the Gravity Equation”, American Economic Review, 69, pp. 106-116.

Anderson, J. E. and E. van Wincoop(2004), "Trade Costs", Journal of Economic Literature, 42(3), pp. 691-751.

Anderson, J. E. and E. van Wincoop(2003), "Gravity with Gravitas: a Solution to the Border Puzzle", American Economic Review, 93(1), pp. 170-192.

Armstrong, S., P. Drysdale and K. Kalirajan(2008), Asian Trade Structures and Trade Potential: An Initial Analysis of South and East Asian Trade, Crawford School of Economics and Government, Australian National University, Sydney.

ARTNeT(2009), ARTNeT Gravity Modelling Initiative on "Behind the Border" Factors Affecting Trade (2008-09), Asia-Pacific Research and Training Network (ARTNeT), ESCAP, Bangkok.

ADB-UNCTAD(2008), Quantification of Benefits from Regional Cooperation in South Asia, Asian Development Bank (ADB) - United Nations Conference on Trade and Development (UNCTAD), Macmillan, New Delhi.

Baier, S. L. and J. F. Bergstrand(2007), Bonus vetus OLS: A Simple Method for Approximating International Trade-cost Effects using the Gravity Equation, available at http://www.nd.edu/ jbergstr/Working_Papers/BVOLSOctober2007.pdf.

Baier, S. L. and J. F. Bergstrand(2001), "The Growth of World Trade: Tariffs, Transport Costs, and Income Similarity", Journal of International Economics, 53, pp. 1-27.

Baldwin, R. E. and D. Taglioni(2007), "Trade Effects of the Euro: a Comparison of Estimators", Journal of Economic Integration, 22(4), pp. 780-818.

Baldwin, R. E. and D. Taglioni(2006), Gravity for Dummies and Dummies for Gravity Equations, Working Paper \#12516, National Bureau of Economic Research, Cambridge.

Batra, A.(2004), India's Trade Potential: The Gravity Model Approach, Working Paper No. 151, Indian Council for Research on International Economic Relations (ICRIER), New Delhi.

Bougheas, S., P. O. Demetriades and E. L. W. Morgenroth(1999), "Infrastructure, Transport Costs, and Trade", Journal of International Economics, 47(1), pp. 169189.

Brooks, D. and D. Hummels(2009), Infrastructure's Role in Lowering Asia's Trade Costs: Building for Trade, Edward Elgar, Cheltenham.

De, P(2006), "Trade, Infrastructure and Transaction Costs: The Imperatives for Asian Economic Cooperation”, Journal of Economic Integration, 21(4), pp. 708-735.

De, P(2008a), "Trade Costs and Infrastructure: Analysis of the Effects of Trade Impediments in Asia", Integration \& Trade Journal, 12(28), pp. 241-266.

De, P(2008b), Empirical Estimates of Trade Costs for Asia, in Infrastructure and Trade in 
Asia (Ed.) D. Brooks and J. Menon, Edward Elgar, Cheltenham.

De, P. and C. Neogi(2009), Global Economic Crisis: Implications for Trade and Industrial Restructuring in South Asia, Paper Presented at the International Conference on "Global Economic Crisis: Impacts and Implications for Industrial Restructuring in Asia”, Organized by the National Cheng Kung University (NCKU), Taiwan; Asian Development Bank Institute (ADBI), Tokyo; and the Asian Productivity Organization (APO), Tokyo; Held at Tainan, Taiwan, on 19-20 August 2009.

Djankov, S., C. Freund and C. S. Pham(2006), Trading on Time, Policy Research Working Paper No. 3909, World Bank, Washington, D.C.

Duval, Y. and C. Utoktham(2009), Behind-the-border Trade Facilitation in Asia-Pacific: Cost of Trade, Credit Information, Contract Enforcement and Regulatory Coherence, Staff Working Paper 2/2009, ESCAP, Bangkok.

Egger, P.(2002), "An Econometric View of the Estimation of Gravity Models and the Calculation of Trade Potentials", The World Economy, 25(2), pp. 297-312.

Egger, P.(2000), "A Note on the Proper Econometric Specification of the Gravity Equation", Economic Letters, 66, pp. 25-31.

ESCAP(2009), Navigating out of the Crisis: A Trade-led Recovery, A Practical Guide for Policymakers in Asia and the Pacific, Bangkok.

Francois, J and M. Manchin(2006), Institutional Quality, Infrastructure, and the Propensity to Export, Centre for Economic Policy Research, London.

Francois, J., M. Manchin and A. P. Balaoing(2009), "Regional Integration in Asia: the Role of Infrastructure", in Pan-Asian Integration: Linking East and South Asia (Ed.) J. Francois, P. B. Rana and G. Wignaraja, Palgrave Macmillan, Basingstoke.

Gorodnichenko, Y and L. L. Tesar(2009), "Border Effect or Country Effect? Seattle May Not Be So Far from Vancouver after All”, American Economic Journal: Macroeconomics, 1(1), pp. 219-241.

Harrigan, J.(2001), Specialization and the Volume of Trade: Do the Data Obey the Laws?, National Bureau of Economic Research Working Paper No. 8675, Cambridge.

Hausman, J. A.(1978), "Specification Tests in Econometrics", Econometrica, 46(6), pp. 1251-1271.

Helble, M., B. Shepherd and J. S. Wilson(2007), Transparency, Trade Costs, and Regional Integration in the Asia-Pacific, Policy Research Working Paper 4401, Development Research Group, World Bank, Washington, D.C.

Helpman, E., M. Melitz and Y. Rubinstein(2008), "Estimating Trade Flows: Trading Partners and Trading Volumes", Quarterly Journal of Economics, 123(2), pp. 441487.

Hoekman, B. and A. Nicita(2008), Trade Policy, Trade Costs and Developing Country Trade, Policy Research Working Paper No. 4797, World Bank, Washington, D.C. International Monetary Fund (IMF)(2009a), Direction of Trade Statistics Yearbook, CDROM March 2009, Washington, D.C.

International Monetary Fund (IMF)(2009b), World Economic Outlook Database April 
2009, Released on 22 April 2009, Washington, D.C.

Jacks, D. S., M. M. Christopher and D. Novy(2008), “Trade Costs: 1870-2000”, American Economic Review, 98(2), pp. 529-534.

Jalan, B.(1993), Indian Economy: Problems and Prospects, Penguin, New Delhi.

Kalirajan, K. and S. Bhattacharya(2007), Free Trade Arrangement between India and Japan: An Exploratory Analysis, Australia South Asia Research Centre Working Paper No. 2007/09, Australia National University, Sydney.

Lamy, P.(2009), Retreating from Market Opening is not a Solution to the Economic Crisis, Speech Delivered to the Peterson Institute for International Economics, 24 April 2009, Washington D.C.

Linnemann, H.(1966), An Econometric Study of International Trade Flows, North Holland Publishing, Amsterdam.

McCallum, J.(1995), National Borders Matter: Canada-US Regional Trade Patterns, American Economic Review, 85(3), pp. 615-623.

Mikic, M. and J. Gilbert(2007), Trade Statistics in Policymaking: A Handbook of Commonly Used Trade Indices and Indicators, ESCAP, Bangkok.

Mohan R.(2009), Global Financial Crisis: Causes, Impact, Policy Responses and Lessons, Reserve Bank of India, Mumbai.

Mohan R.(2008), Global Financial Crisis and Key Risks: Impact on India and Asia, Speech Delivered at the IMF-FSF High-Level Meeting on the Recent Financial Turmoil and Policy Responses, 9 October 2008, Washington, D.C.

Moktan, S.(2008), "Evaluating the Intra-regional Exports and Trade Creation, and Trade Diversion Effects of Trade Agreements in SAARC Countries", South Asia Economic Journal, 9(2), pp. 233-260.

Moreira, M. M., C. Volpe and J. S. Blyde(2008), Unclogging the Arteries: The Impact of Transport Costs on Latin American and Caribbean Trade, Inter-American Development Bank (IDB), Washington, D. C.

Nordås, H. K. and R. Piermartini(2004), Infrastructure and Trade, Staff Working Paper ERSD-2004-04, Economic Research and Statistics Division, World Trade Organization (WTO), Geneva.

Poyhonen, P.(1963), "A Tentative Model for the Volume of Trade between Countries", Weltwirtschaftliches Archiv, 90(1), pp. 93-99.

Rakshit, M.(2009), "India Amidst the Global Crisis", Economic and Political Weekly, 44(13), pp. 94-106.

Research and Information System for Developing Countries (RIS)(2009), South Asia Development and Cooperation Report 2008, Oxford University Press, New Delhi.

Reserve Bank of India (RBI)(2009), Annual Policy Statement 2009-10, 21 April 2009, Mumbai.

Rose, A.(2000), "One Money, One Market: Estimating the Effect of Common Currencies on Trade", Economic Policy, 15, pp. 7-46.

Santos Silva, J. M. C. and S. Tenreyro(2006), "The Log of Gravity", The Review of Economics and Statistics, 88(4), pp. 641-658. 
Shepherd, B.(2008), Notes on the 'Theoretical' Gravity Model of International Trade, Background Paper for ARTNeT 2008 Capacity-Building Workshop for Trade Research: "Behind the Border" Gravity Modelling, 15-19 December 2008, Bangkok. Shepotylo, O.(2009), Gravity with Zeros: Estimating Trade Potential of CIS Countries, Kyiv School of Economics and Kyiv Economics Institute, Kyiv, available at http:// ssrn.com/abstract $=1347997$.

Subbarao, D.(2009), India: Managing the Impact of the Global Financial Crisis, Speech Delivered at the 2009 National Conference and Annual Session, 26 March 2009, Confederation of Indian Industry (CII), New Delhi.

Tinbergen, J.(1962), Shaping the World Economy: Suggestions for an International Economic Policy, The Twentieth Century Fund, New York.

Wilson, J. S., C. L. Mann and T. Otsuki(2005), "Assessing the Benefits of Trade Facilitation: a Global Perspective", The World Economy, 28(6), pp. 841-871.

World Bank(2009), World Development Report 2009, Washington, D.C.

World Trade Organization (WTO)(2009a), World Trade 2008, Prospects for 2009, Press Release No. 554, 23 March 2009, Geneva.

World Trade Organization (WTO)(2009b), Report of the TRPB from the Director-General on the Financial and Economic Crisis and Trade-related Development, 26 March 2009, Geneva. 